\title{
Minimizing Formation Damage in Drilling Operations: A Critical Point for Optimizing Productivity in Sandstone Reservoirs Intercalated with Clay
}

\author{
Michael Chuks Halim, Hossein Hamidi *(D) and Alfred R. Akisanya (D) \\ School of Engineering, King's College, University of Aberdeen, Aberdeen AB24 3UE, UK; \\ r01mch17@abdn.ac.uk (M.C.H.); a.r.akisanya@abdn.ac.uk (A.R.A.) \\ * Correspondence: hossein.hamidi@abdn.ac.uk
}

Citation: Halim, M.C.; Hamidi, H.; Akisanya, A.R. Minimizing Formation Damage in Drilling Operations: A Critical Point for Optimizing Productivity in Sandstone Reservoirs Intercalated with Clay. Energies 2022, 15, 162. https://doi.org/10.3390/en15010162

Academic Editor: Mofazzal Hossain

Received: 9 November 2021

Accepted: 9 December 2021

Published: 27 December 2021

Publisher's Note: MDPI stays neutral with regard to jurisdictional claims in published maps and institutional affiliations.

Copyright: (C) 2021 by the authors. Licensee MDPI, Basel, Switzerland. This article is an open access article distributed under the terms and conditions of the Creative Commons Attribution (CC BY) license (https:// creativecommons.org/licenses/by/ $4.0 /)$.

\begin{abstract}
The recovery of oil and gas from underground reservoirs has a pervasive impact on petroleum-producing companies' financial strength. A significant cause of the low recovery is the plugging of reservoir rocks' interconnected pores and associated permeability impairment, known as formation damage. Formation damage can effectively reduce productivity in oil- and gas-bearing formations - especially in sandstone reservoirs endowed with clay. Therefore, knowledge of reservoir rock properties - especially the occurrence of clay-is crucial to predicting fluid flow in porous media, minimizing formation damage, and optimizing productivity. This paper aims to provide an overview of recent laboratory and field studies to serve as a reference for future extensive examination of formation damage mitigation/formation damage control technology measures in sandstone reservoirs containing clay. Knowledge gaps and research opportunities have been identified based on the review of the recent works. In addition, we put forward factors necessary to improve the outcomes relating to future studies.
\end{abstract}

Keywords: formation damage; clay mineralogy; reservoir rock; optimizing productivity; permeability impairment; wellbore

\section{Introduction}

Despite significant achievements in reducing the costs of renewable energy technologies and their recent embracement, oil and gas still account for more than $75 \%$ of overall energy utilised — especially in developing countries [1] —and 60\% of global energy used [2]. Consequently, the total energy consumption is expected to rise at $1.5 \%$ per year in energy demand over 2015-2040 [3]. Although there is increasing demand for and utilisation of renewable energy in developed countries, which is anticipated to continue to grow as these countries work towards achieving their very ambitious climate change targets, the adoption and use of renewable energy sources have been negligibly small in many developing and middle-income countries. Consequently, undisrupted supply of and access to oil and gas contributing to the energy mix in a net-zero economy would help to address energy poverty and provide affordable, reliable, and efficient energy services to end users in many developing and middle-income countries.

Oil and gas exploration involves finding and extracting hydrocarbons to refine and selling processed petroleum products. It requires enormous financial investment and longer delivery times to discover and produce oil and gas in troubled formations with great risk. The natural oil and gas resources found by major petroleum-producing companies are their most significant commercial resources; thus, the source of funding for these companies lies in their ability to recover the oil and gas reserves from oil- and gas-bearing formations $[4,5]$.

A significant cause of low recovery of petroleum from petroleum-producing formations is a process known as formation damage. Formation damage can be defined as the plugging of the pore network of the formation which then results in decrease in the rate of 
production of underground reservoirs, and in some cases can also result in decrease in the rate of water or gas injection in injection wells [6]. Formation damage is inevitable and can occur while operations such as producing the well, stimulating the reservoir, utilisation of drilling fluids, and working over and completing wells are ongoing in the well's lifespan. Formation damage can result from many factors, one of which is the interaction of the drilling fluids with the underground reservoir-especially during the drilling of barefooted sandstone reservoirs [6-8].

Since formation damage inhibits the flow of fluids through porous formations, the characterisation of formation properties that affect the fluid flow through underground reservoirs-mainly interconnected pore networks or permeability-has found an application in predicting pore throat size and distribution as well as the degree of change in the formation properties [9].

Pressure drawdown data obtained from many wells in different oil fields indicate that the wells produced less than their potential production capacity because of permeability alterations and/or plugging of pores around the wellbore [10]. Permeability alterations around the wellbore can reduce the productivity of completed wells. The intensity of permeability alterations or plugging of pores is influenced by the efficiency of the drilling fluid, because an efficacious drilling fluid can generate a thin filter encrust that minimises the permeation of the filtrate, which is the first source of formation damage.

As soon as extreme decline in the productivity of completed wells begins due to severe damage, operational funding becomes valueless [11]. Therefore, economic failure during the development of these oil fields may occur due to well abandonment or the shortened lifespan of fields, unless the physicochemical changes due to interaction between drilling fluids and varying clay minerals causing the reduction in permeability are adequately understood and mitigated.

The principal mechanism leading to formation damage is the interaction between discontinuous and continuous phases in the drilling/completing fluid or stimulation fluid with the rocks and pore-fluids of reservoirs [12]. Formation damage can significantly reduce the productivity in both oil- and gas-bearing formations, especially in sandstone reservoirs endowed with varying clay minerals [12-14]. These clay minerals are highly unstable, reactive and, for the most part, have habits/morphology that are outcropped as pore-lining, pore-bridging, and pore-filling along the micropore structural walls, and are inevitably in contact with drilling fluids (both solids and filtrates) that have invaded the micropore structure. These clay minerals, with a size ranging from $1 \mu \mathrm{m}$ to $5 \mu \mathrm{m}$ along their longest diameter, are known as "fines" in the sandstone reservoir [13]. The interaction of clay minerals with invasive drilling fluids can detrimentally alter the transmissibility of oil and gas, thereby posing a major formation damage challenge.

Due to the negative economic impact of formation damage on hydrocarbon production, the formulation of drilling fluids with characteristics that minimise formation damage has been a major focus of the petroleum industry personnel and researchers since the 1970s-1980s. In this paper, recent advancements and corresponding improved strategies against permeability alterations ultimately leading to productivity impairment in claycontaining sandstone reservoirs are outlined for the purpose of understanding the extent of developments in this area. The focus of the current paper is to give a summary of several kinds of formation damage challenge associated with clay minerals in petroleum sandstone rocks. We then proffer solutions regarding technology related to the formation damage mitigation/formation damage control (FDM/FDC) measures that can be used to overcome these challenges in sandstone reservoirs with varying clay minerals.

\section{Formation Damage Mechanisms}

Formation damage refers to permeability impairment due to blocked pore throats in hydrocarbon-bearing formations-the result of rock-fluid and fluid-fluid interactions around the near-wellbore region. Interaction between clay minerals and drilling fluids is an example of rock-fluid interaction reducing well productivity (Figure 1). 


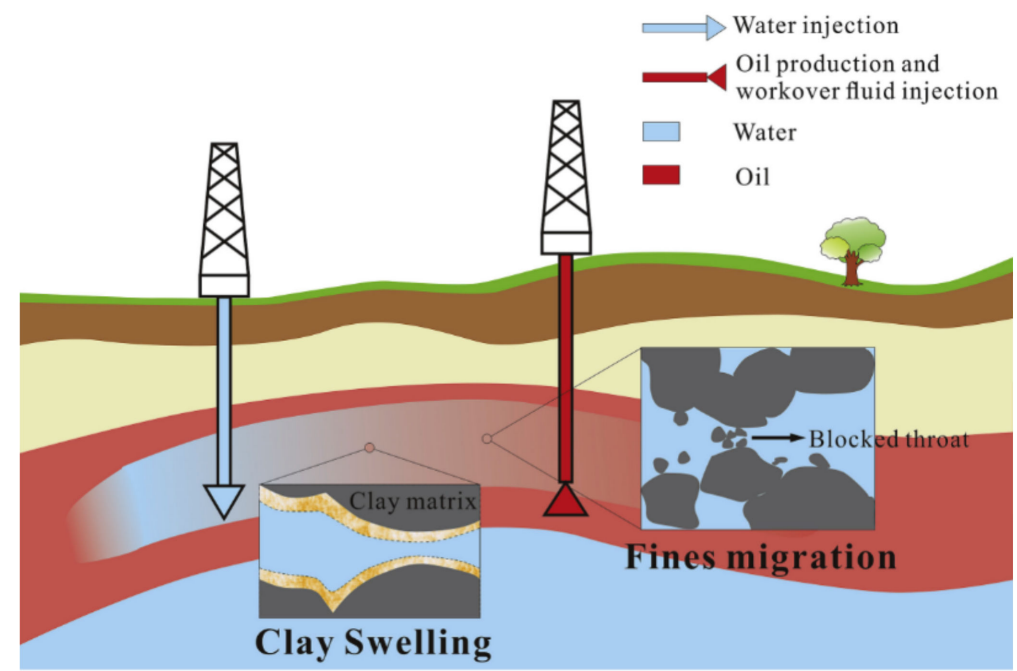

Figure 1. Illustration of permeability alterations caused by swelling of clay and migration of fines near the wellbore region after rock-fluid interaction. Taken from [15].

The well productivity performance reduces due to formation damage, and expensive treatment is usually required in order to remove drilling-operation-related damage. Bennion [6] attempted to categorise formation damage mechanisms in porous media such as sandstone, and stated that there are four primary mechanisms through which formation damage occurs in porous media-namely, mechanical, chemical, biological, and thermal (Figure 2).

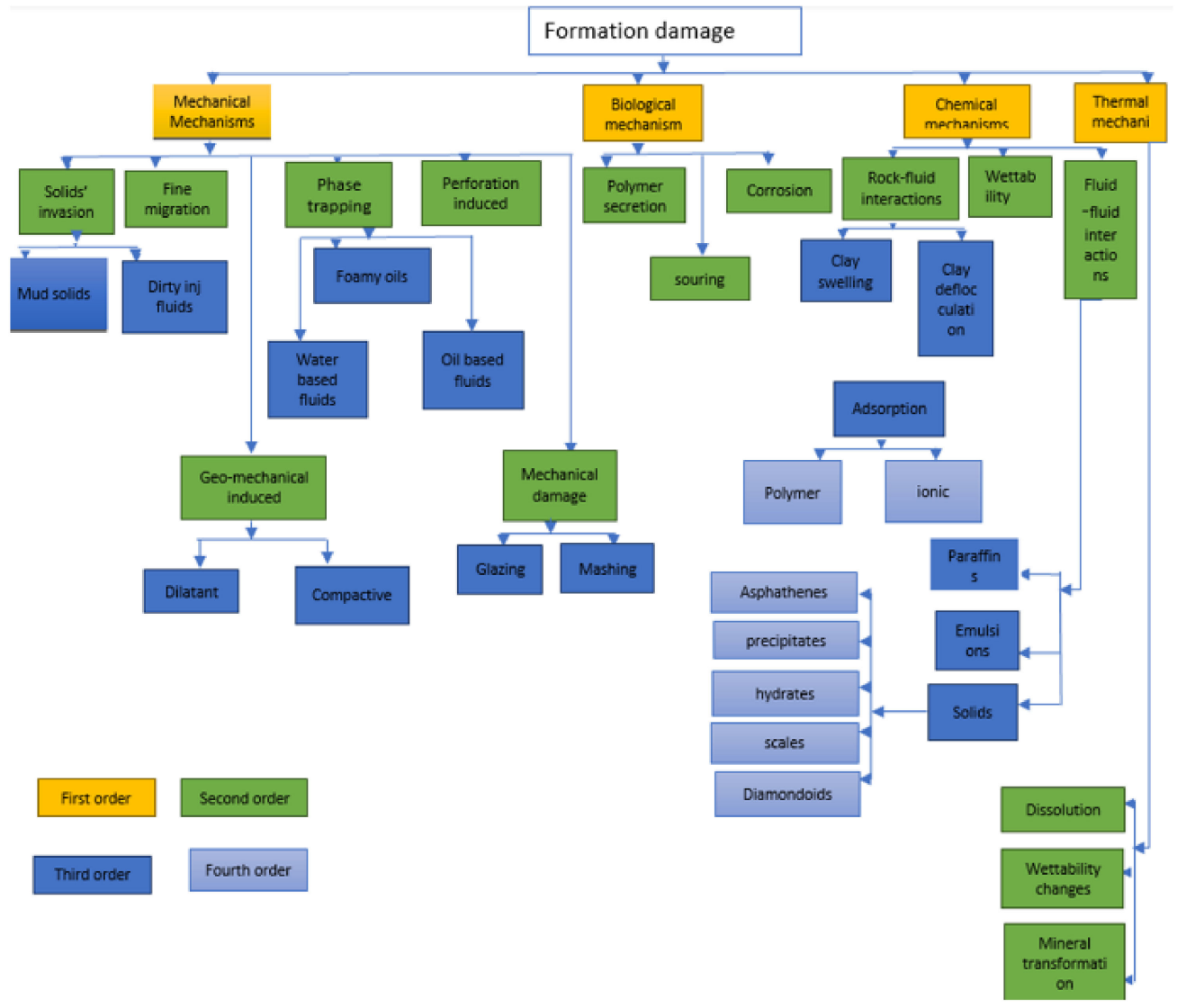

Figure 2. Category of formation damage mechanisms in sandstone, adapted from [6]. 
These mechanisms inhibit the transmissibility of formation fluids from reservoirs into wellbores and, consequently, impair hydrocarbon production rates and well productivity [16-19].

\section{Formation Damage Mechanisms in Sandstone}

Oil and gas operational activities_-including stimulating, completing, and producing wells-strongly influence the permeability of sandstone reservoirs with varying clay minerals around the near-wellbore regions. During the development of sandstone reservoirs with varying clay minerals, several damage reaction mechanisms are triggered, especially during drilling, completion, stimulation, and production processes. The main damage reactions associated with such processes have been categorised as mechanical damage, chemically induced damage, biological damage, and thermal damage [2-4].

\subsection{Mechanical Mechanisms}

Mechanical mechanisms can result from all immediate, unrelated, or chemically induced interactions between the rock and equipment or fluid that lead to reduction in permeability $[6,20]$. Overbalance drilling can enhance safety during drilling operation because it prevents taking of a kick (inflow of formation fluids) and, ultimately, blow-out; however, it can lead to invasion of solids and filtrates from drilling fluids due to pressure in excess of the reservoir pressure (Figure 3). Invasion of the fine colloidal materials and filtrates into the near-wellbore region of the sandstone reservoir can reduce the intrinsic permeability by plugging the pore throats within the micropore structural network. Generally, sandstone reservoirs with permeability of less than $5 \times 10^{-15} \mathrm{~m}^{2}$ are considered to be tight, while those with permeability of less than $1 \times 10^{-15} \mathrm{~m}^{2}$ are considered to be very tight, and those with permeability of more than $25 \times 10^{-15} \mathrm{~m}^{2}$ are considered to be high [21]. The obstruction of the micropore networks due to external solid particles and fluids can extend to a radius greater than 1 foot into the pay-zone of sandstone reservoirs with permeability of more than $25 \times 10^{-15} \mathrm{~m}^{2}$ [5]. Fine migration can be defined as the movement of native, micronized quartz grains or clay minerals in the micropore structural network due to extreme flow rate, while solid entrainment is the invasion of particles from introduced fluids into formation pores and the plugging of the pore network [22]. The fine colloidal materials and filtrate of the drilling fluid deeply invade the sandstone reservoir with varying clay minerals, inducing severe formation damage $[19,23,24]$. The associated mechanical formation damage reactions include occlusion of pore throats by fine colloidal solids (Figure 3), filtrate invasion (which subsequently forms part of the permeating fluids), phase trapping and, ultimately, formation damage reactions due to rock-permeating fluid interactions $[6,25]$.

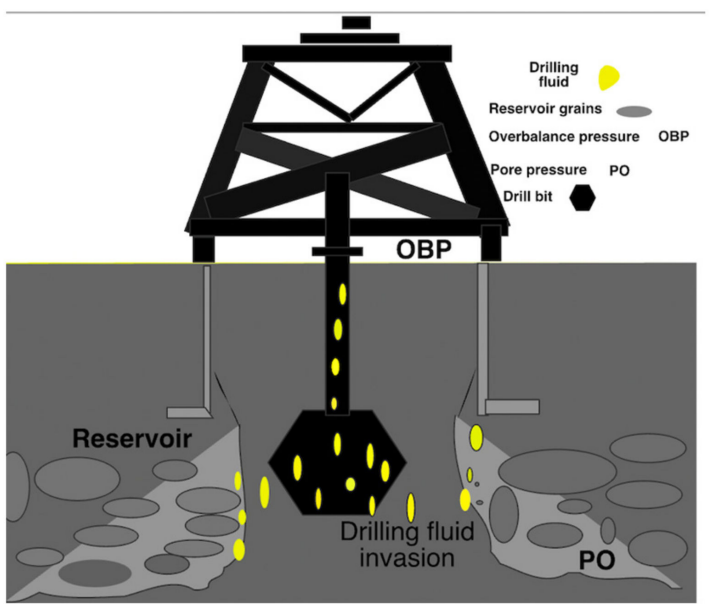

Figure 3. Drilling fluid invasion formation damage reactions caused by overbalance drilling. 


\subsection{Chemical Mechanisms}

The invasive filtrate from drilling fluids forms part of the permeating fluids in the sandstone reservoir, causing chemical damage mechanisms such as clay swelling, clay deflocculation, flocculation as a result of unfavourable clay mineral-filtration loss interactions, and unfavourable reservoir formation-permeating fluid interactions [6]. Clay swelling is the interaction and hydration of hydrophilic materials, including smectite-rich mixed layers (smectite + illite), via reactions involving deionised or moderately saline water [6] (Figure 4).

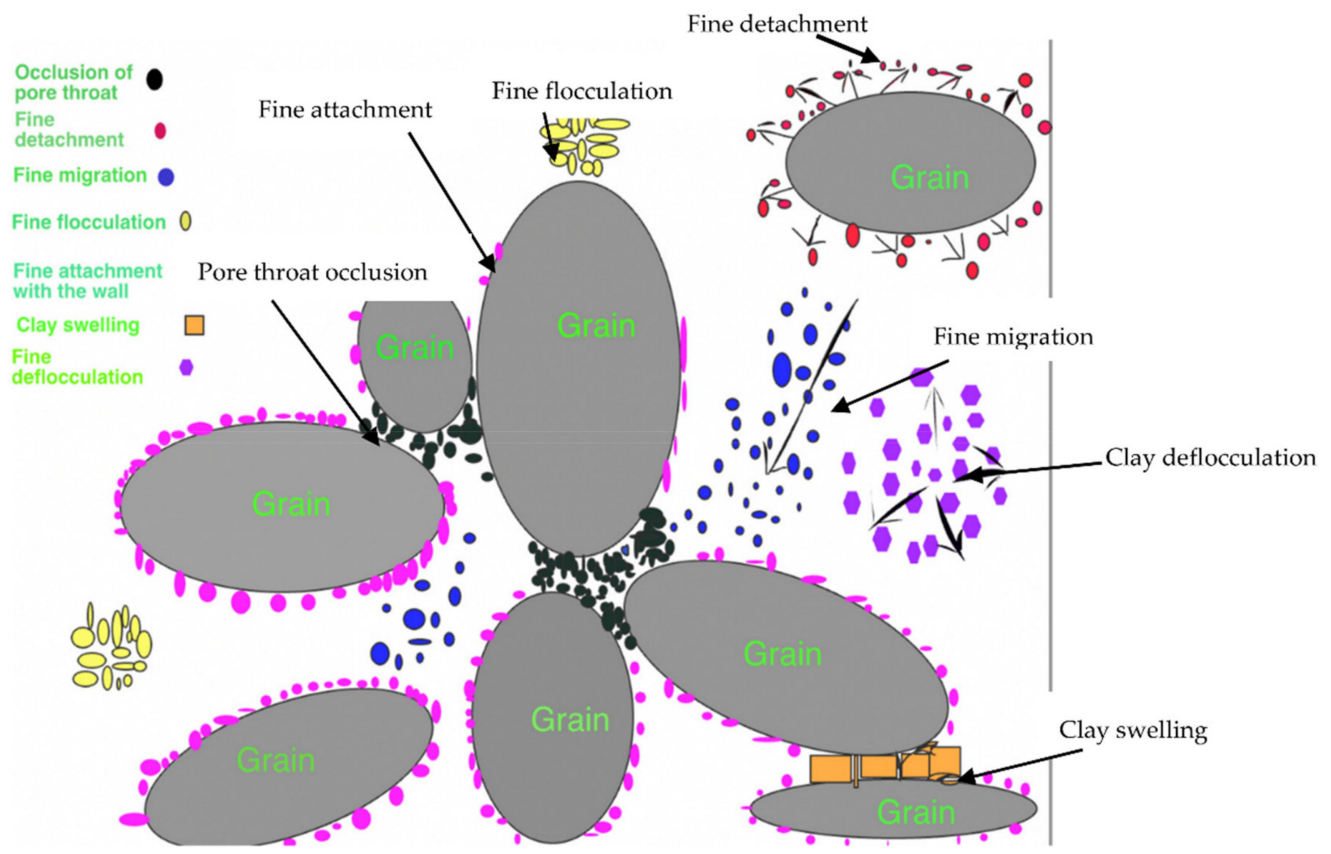

Figure 4. The effects of interaction between the different mechanisms on formation damage.

The metallic ions inside the formation fluid form a stable system with the cations on the surfaces of the clay minerals; hence, the clay minerals are attracted and attached to the micropore structural walls [16]. The permeating fluids alter the native salinity in the micropore structure of the sandstone reservoir rock as they very slowly permeate through the micropore structure. Depending on the degree and rate of change in salinity, these clay minerals may undergo sudden detachment from the walls of the micropore structure [26]. Alteration in salinity affects the electric charges moving between the fines of clay minerals and the rock surface, thereby influencing the separation of fines from larger rock grains [26]. A decrease in salinity makes the charges move farther apart from one another [26], debilitating the attraction between the attached clay particles and the rock surface, which may cause fines to be detached and mobilised by the force due to the viscosity of the permeating fluid [27].

The detached fines of clay minerals are suspended as fines in the permeating fluid, and the formation damage reaction due to migration is initiated, leading to occlusion of pore throats and decreasing permeability. Sharma [22] has shown that fine blockage around narrow micropores is controlled by a specific quantity of micronized dispersed solids and a specific flowrate, including narrow micropore size configurations within sandstone reservoirs [22]. This transient salinity does not only trigger damage reactions, but also modifies the $\mathrm{pH}$ of the volume of filtration loss via an ionic interchange taking place between metallic ions on the walls of mineral grains-such as sodium - and protons in $\mathrm{H}_{2} \mathrm{O}$ [8]. This resulting $\mathrm{pH}$ is generated via in situ ion exchange because sandstone reservoirs composed of clay minerals act as cation exchangers and have been shown to exchange $\mathrm{Na}^{+}$for $\mathrm{H}^{+}$[28-30]. The other source of $\mathrm{pH}$ is sustained via the extraneous fluid. 
Drastic differences in $\mathrm{pH}$ and salinity between permeating fluid and formation fluid can cause swellable clay; when several species of cation are present in a clay-brine system, the properties of the clay are influenced by the base interchange reactivity. The base interchange stability value favours the attachment of metallic ions with valency above two over metallic ions with a valency of one. Additionally, if metallic ions with valency above two are in the base interchange positions, the flocculated clay particles do not deflocculate, regardless of $\mathrm{H}_{2} \mathrm{O}$ salinity; therefore, permeability impairment is avoided.

\subsection{Biological Mechanisms}

Biological formation damage is a result of the direct chemical interaction between microbes and food substances in sandstone reservoirs [31]. In the course of drilling with water-based fluids and water injection operations, including the maintenance of depleting reservoir pressure in water-driven reservoirs, microbes are brought into the sandstone reservoir [31]. The presence of bacteria in sandstone reservoirs is widely acknowledged [32]. The three different categories of biological damage mechanism are blocking, corrosion, and toxicity [31]. Organic compounds with very heavy molecular weight produced by these microbes can stick to the outer parts of pore walls, acting as pore-filling and pore-lining bacteria, by means of which narrow micropore structural networks are occluded, ultimately reducing permeability in the formation [31] and, eventually, plugging it [32]. Microbes or bacteria can trigger oxidation reactions involving loss of hydrogen a result of corrosion, pitting, and stress cracking of downhole and surface equipment [31]. Microbes or bacteria can also trigger the loss of sulphates, ultimately producing hydrogen sulphide gas, which can have adverse health impacts on rig personnel throughout drilling operations; these bacteria are either natives of the reservoir or have been brought into the reservoir during drilling operation [33]. Mcgovern-Traa et al. [33] reported that the behaviour of these bacteria under reservoir conditions are not completely understood [33]. However, if these sulphatereducing bacteria $(\mathrm{SRB})$ are indigenous and feed on nutrients contained in reservoir drilling fluid (RDF) or injected water, this means that the associated formation damage reactions will extend beyond the near-wellbore region, reaching rather deep into the sandstone reservoir [34]. Maudgalya and McInerney [35] proposed the use of microbes to improve oil recovery for a better tertiary oil recovery technique, because naturally existing microbes can be utilised, helping to mitigate adsorption and other losses due to degradation [35]. In related research on the implementation of a tertiary microbial-enhanced oil recovery (MEOR) technique in sandstone-producing formations [36], Chakraborty et al. [36] studied the mechanism of microbial growth, its metabolism, and production of biosurfactants within sandstone reservoirs using first-order Monod kinetics, stating that the detailed mechanism behind the wettability alteration of mineral surfaces observed during the MEOR process is not yet fully understood; they observed that combined findings from the relative permeability and fractional flow profiles reveal that during the MEOR process, as time increases, the efficiency of oil mobilisation and flow within the sandstone core reduce steadily, and the water breakthrough is simultaneously preponed. Chakraborty et al. [36] concluded that a major explanation behind this phenomenon may be bioclogging-induced formation damage, which can occur mostly when the dominant factor-porosity-is lower than $24 \%$ [36]. Wood and Spark [37] studied bacterial induced damage-reaction mechanism in producing formations. They were utilising microbial bottle and flood analysis conducted at different temperatures up to the actual producing formation temperature modelled the microbial formation damage mechanisms. Wood and Spark [37] observed that native microbes can interact in different ways and induce formation damage reactions based on the different temperature values in the different regions of the reservoir, whereby those regions of the reservoir with temperature values of $\sim 120^{\circ} \mathrm{C}$ are habitats for pore-lining native bacteria, capable of inducing insignificant damage reactions, but those regions of the reservoir with temperature values of $\sim 60^{\circ} \mathrm{C}$ are home to a small number of pore-blocking microbes, which can induce significant damage reactions only when the population of the microbial community becomes large enough to occlude narrow micropore networks [37]. 
Wood and Spark [37] concluded that RDF produced organic compounds with heavy molecular weight and microbes at $30^{\circ} \mathrm{C}$, although a small volume of $\mathrm{H}_{2} \mathrm{~S}$ gas evolved and was noticeable on produced $\mathrm{H}_{2} \mathrm{O}$ at the producing wells [37]. We acknowledge that temperature is a prime factor controlling the biological formation damage reactions due to microbes, and agree with Irene [31] that additives such as chemicals used to suppress microbes or oxygen-removing substances, when used for formulating RDF, can avert microbial damage reactions [31]. However, the relationship between formation damage reactions and porosity, as a dominant factor determining the effective use of bacteria and nutrients in the MEOR process, has not been fully understood, and needs scrutiny during oilfield development because the porosity of sandstone reservoirs is influenced by so many microscopic featuresespecially clay minerals-and this can create sharp disparities in porosity and heterogeneity within a radius of $2-5 \mu \mathrm{m}$ inside the micropore structural space.

\subsection{Thermal Mechanisms}

Thermal damage mechanisms can be a result of exploration and production activities with extreme temperatures throughout an enhanced oil recovery (EOR) operation, including steam injection and combustion-gas-heavy oil interaction [31]. Thermal decay of petroleum and formation minerals containing $\mathrm{SO}_{4}{ }^{2-}$, at temperatures greater than $200{ }^{\circ} \mathrm{C}\left(390{ }^{\circ} \mathrm{F}\right)$, may produce poisonous gases, including hydrogen sulphide and carbon (IV) oxide [31]. Mineral disintegration and alterations can occur at temperatures greater than $250{ }^{\circ} \mathrm{C}\left(480^{\circ} \mathrm{F}\right)$, and such alterations under catalytic conditions can make clay minerals that were less reactive become very reactive, displaying various formation damage reactions-including clay swelling, fine flocculation, and deflocculation — and may lead to severe reduction in reservoir permeability [31].

\subsection{Remarks}

Formation damage reactions due to mechanical mechanisms can be very extensive, including migration of fines, entrainment of external solids, discontinuous dispersion and occlusion of fluids, glazing and mashing, damage reactions due to perforations, and widening of micropore openings with small, abrasive solid materials. Mechanical damage mechanisms can occur in combination with other damage mechanisms within the pore structure of sandstone reservoirs containing varying clay minerals, and the resulting formation damage can be severe. For example, fine migration (a mechanical formation damage reaction) can occur simultaneously with clay swelling (a chemical formation damage reaction). In some situations, changes in the $\mathrm{pH}$ and salinity (from high to low) of permeating fluids can create repulsive actions in the double-electrostatic system, leading to physical separation between clay minerals and pore walls during drilling operations. The amounts of fines detached from grain surfaces also depend on flow rate, and are suspended in the permeating fluid, which controls the processes of fine migration and solid entrainment. The extent of the reduction in permeability is influenced by the presence of smectite and whether the permeating fluid encounters swellable clay, depending on the diameter of the narrow micropore structures, which is consistent with the findings of Zhao et al. [11].

A list of the most common formation damage mechanisms found in sandstone reservoirs is presented in Table 1.

Numerous contemporary studies, such as those cited in Table 1, reveal that the most significant formation damage mechanisms are mechanical mechanisms, judging from a statistical perspective, while thermal mechanisms are mostly insignificant during drilling operations, based on both experimental and field data (Figure 5). 
Table 1. List of common formation damage mechanisms found in sandstone reservoirs with varying clay minerals.

\begin{tabular}{|c|c|c|c|c|}
\hline $\begin{array}{l}\text { Main Damage } \\
\text { Mechanisms }\end{array}$ & $\begin{array}{c}\text { Formation Damage } \\
\text { Reaction(s) }\end{array}$ & $\begin{array}{l}\text { Determinant } \\
\text { Factor(s) }\end{array}$ & $\begin{array}{l}\text { Resultant } \\
\text { Effect(s) }\end{array}$ & References \\
\hline \multirow{4}{*}{$\begin{array}{l}\text { Mechanical } \\
\text { mechanisms }\end{array}$} & Fine migration & Flow rate $/ \mathrm{pH}$ & $\begin{array}{l}\text { Occlusion of pore } \\
\text { throats }\end{array}$ & [38-44] \\
\hline & $\begin{array}{c}\text { Colloidal } \\
\text { material/fluid } \\
\text { invasion }\end{array}$ & $\begin{array}{c}\text { Pressure } \\
\text { differential }\end{array}$ & $\begin{array}{l}\text { Internal filter } \\
\text { cakes clogging } \\
\text { pores }\end{array}$ & [45] \\
\hline & $\begin{array}{l}\text { Phase trapping } \\
\text { damage }\end{array}$ & Immiscibility & $\begin{array}{c}\text { Adverse } \\
\text { permeability }\end{array}$ & {$[6,46-49]$} \\
\hline & Tensile deformation & $\begin{array}{l}\text { Weakened } \\
\text { grain fabric }\end{array}$ & $\begin{array}{l}\text { Alteration of pore } \\
\text { networks and } \\
\text { mineral surfaces }\end{array}$ & [50-53] \\
\hline \multirow[b]{2}{*}{$\begin{array}{l}\text { Chemical } \\
\text { mechanisms }\end{array}$} & Clay swelling & Low salinity & $\begin{array}{l}\text { Expansion inside } \\
\text { micropore } \\
\text { structures }\end{array}$ & {$[54]$} \\
\hline & $\begin{array}{c}\text { Dispersion and } \\
\text { flocculation of clay } \\
\text { minerals; precipitation } \\
\text { of salts }\end{array}$ & $\begin{array}{l}\mathrm{pH} \text { and high } \\
\text { salinity }\end{array}$ & $\begin{array}{l}\text { Fine suspensions } \\
\text { and constraints }\end{array}$ & {$[11,55]$} \\
\hline $\begin{array}{l}\text { Biological } \\
\text { mechanisms }\end{array}$ & $\begin{array}{c}\text { Growth and } \\
\text { dispersion of microbes } \\
\text { and release of } \\
\text { hydrogen sulphide } \\
\text { gas by } \\
\text { sulphate-reducing } \\
\text { bacteria (SRB) }\end{array}$ & $\begin{array}{l}\text { Porosity less } \\
\text { than } 24 \% ; \\
\text { temperature }\end{array}$ & $\begin{array}{l}\text { Bioclogging of } \\
\text { pore throats }\end{array}$ & {$[19,36,37]$} \\
\hline $\begin{array}{l}\text { Thermal } \\
\text { mechanism }\end{array}$ & $\begin{array}{l}\text { Thermal decay of } \\
\text { petroleum and } \\
\text { formation minerals } \\
\text { containing } \mathrm{SO} 4^{2-}\end{array}$ & $\begin{array}{l}\text { Temperature } \\
\text { greater than } \\
200{ }^{\circ} \mathrm{C}\end{array}$ & $\begin{array}{l}\text { Less reactive clay } \\
\text { becomes very } \\
\text { reactive leading to } \\
\text { clay swelling, fine } \\
\text { flocculation and } \\
\text { deflocculation }\end{array}$ & [31] \\
\hline
\end{tabular}

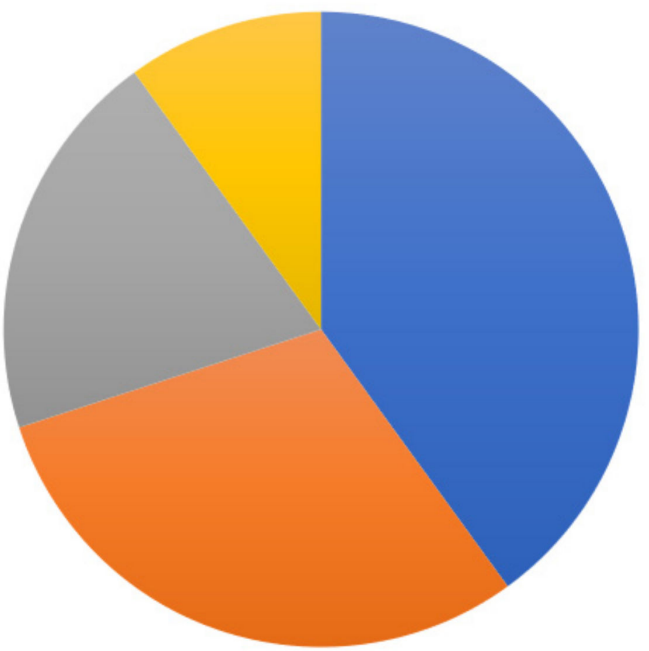

Mechanical damage reaction mechanism $\mathbf{m}$ Chemical damage reaction mechanism

= Biological damage reaction mechanism $\quad$-Thermal damage reaction mechanism

Figure 5. Statistics of formation damage occurrence during drilling operations for sandstone formations. 


\section{Underground Reservoir-Drilling Fluid Interaction-Related Formation Damage}

The two most important factors used to characterise the ionic conditions of drilling fluids that are used in sandstone reservoirs containing clay are $\mathrm{pH}$ and salinity. However, molar ratios and the valency of the ions also become important when fluids are composed of a mixture of ions $[28,56,57]$. Using drilling fluids at low $\mathrm{pH}$ can minimise clay dispersion in sandstone reservoirs; therefore, formation damage can be minimised $[26,58,59]$.

Vaidya and Fogler [60] studied the integrated results of changes in salinity and $\mathrm{pH}$ of injection fluid on formation damage; they used Berea sandstone containing clay to perform two different types of experiments: in one set, solutions with increasing $\mathrm{pH}$ were injected; in the other set, the injection salinity ( $\mathrm{NaCl}$ concentration) was gradually reduced. Vaidya and Fogler [60] observed that if the $\mathrm{pH}$ of the injected fluid reaches extreme levels, the surface potential of Berea sandstone and the micronized particles moves to extremely negative levels [60]. The alteration in this surface potential generates an important repelling force, triggering colloidally induced disconnected mineral particles and, finally, giving rise to adverse permeability reduction [60]. Vaidya and Fogler [60] concluded that ionic conditions of low salinity and high $\mathrm{pH}$ appear to be detrimental to formation permeability, causing migration of fines and drastic damage [60]. The focus of Vaidya and Fogler [60] was kaolinite-the predominant migrating species in Berea sandstone-but it is equally important to also consider formation damage reactions taking place in sandstone with two or more clay species.

Zhang et al. [61] studied damage reaction mechanisms due to water-alkali interactions in a clay-enriched reservoir of Dongping's oil-/gas-producing formations located in Qaidam Basin; they observed that mechanical damage mechanisms are influenced by pore size, and can vary from one pore size to another, concluding that micropore structures with smaller diameter were plugged due to swelling of mixed-layer (illite + smectite) clay minerals, and micropore structures with larger diameter were occluded from the integrated damage reaction involving smectite clay minerals that swelled to many times its original volume, as well as the movement of hair-like illitic minerals [61]. The findings of Zhang et al. [61] indicate that pore-throat size is a dominant factor in clay-mineral-related formation damage reactions, which is consistent with the findings of Zhao et al. [11].

Bennion [6] observed that the expansion plus removal of layers of those clays could cause a drastic decrease in permeability, depending on the amount and location of the clay in the pore system. Extremely saline liquid phases, glycols, heavy metallic ionic organic compounds, amines, and other inhibitors are frequently used to stabilise clays of this type in a contracted or dehydrated state [6]. Clay deflocculation is less understood but more often encountered in sandstone reservoirs than clay swelling. Kaolinitic species are an example of non-water-sensitive clay that can be deflocculated in specific situations, and this can be mitigated by preventing excessive cation exchange and sharp or extreme differences in $\mathrm{pH}[6]$.

There is a strong tendency for fine migration to occur in sandstone reservoirs of varying clay minerals after interaction with drilling fluids, because of corrosion and erosion, flocculation, and deflocculation of clay minerals; these factors were not considered by Bennion [6]. Therefore, we have modified Figure 2 on common formation damage mechanisms to include corrosion and erosion, deflocculation, fine migration, and authigenic precipitation, which is a sixth-order damage mechanism under chemical mechanisms/rock-fluid interactions (Figure 6).

In another study on chemical mechanisms/rock-fluid interactions, Wuyep et al. [50] studied the geomechanical impact of various liquids used in the petroleum industry on sand failure in oil-/gas-producing formations located in the Niger Delta Basin; they evaluated the impact of oilfield chemicals (ATMP (AminoTri(Methylene Phosphonic acid) $\left(\mathrm{C}_{3} \mathrm{H}_{12} \mathrm{NO}_{9} \mathrm{P}_{3}\right)$, glycine betaine $\left(\mathrm{C}_{5} \mathrm{H}_{11} \mathrm{NO}_{2}\right)$, and glutaraldehyde $\left(\mathrm{C}_{5} \mathrm{H}_{8} \mathrm{O}_{2}\right)$ solution) on the geomechanical strength of sandstone reservoir rocks from the Niger Delta using various experimental techniques (mechanical tests, mineral particle diameter arrangement analysis, and analytical tests) to estimate the impact of these liquids on the rock-fluid damage 
mechanism. Through clay mineral characterisation, they observed a significant growth of chlorite from $6 \mathrm{wt} . \%$ to $27 \mathrm{wt} . \%$ and $24 \mathrm{wt} . \%$ when exposing the core samples to ATMP and glutaraldehyde, respectively; with little or no alteration during exposure to betaine, kaolinitic species (45 wt.\% in pre-treatment core samples) diminished to $33 \mathrm{wt} . \%$ and $40 \mathrm{wt} . \%$ due to exposure to betaine and ATMP, respectively [50]. A slight growth of illitic species from $2 \mathrm{wt} . \%$ to $4 \mathrm{wt} . \%$ and $5 \mathrm{wt} . \%$ with ATMP and glutaraldehyde, respectively, was recorded; at the same time, the mixed layer (illite + smectite) that moved towards pure smectite with $100 \%$ expansion in the pre-treatment core samples was altered from $47 \mathrm{wt} . \%$ to $58 \mathrm{wt} . \%, 29 \mathrm{wt} . \%$, and $27 \mathrm{wt} . \%$ after exposure to betaine, ATMP, and glutaraldehyde, respectively (Figure 7) [50].

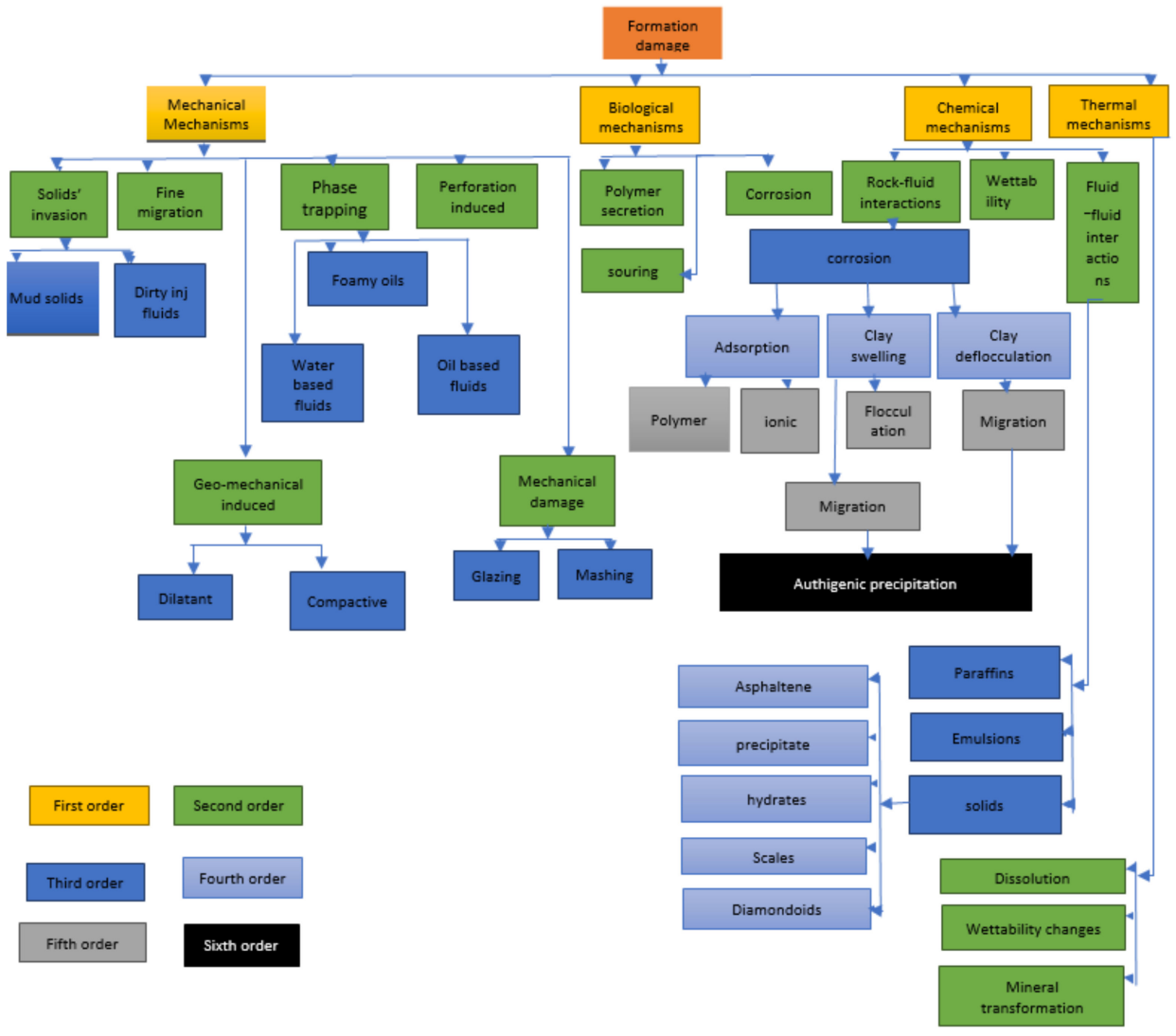

Figure 6. Category of formation damage mechanisms in sandstone, modified from [6].

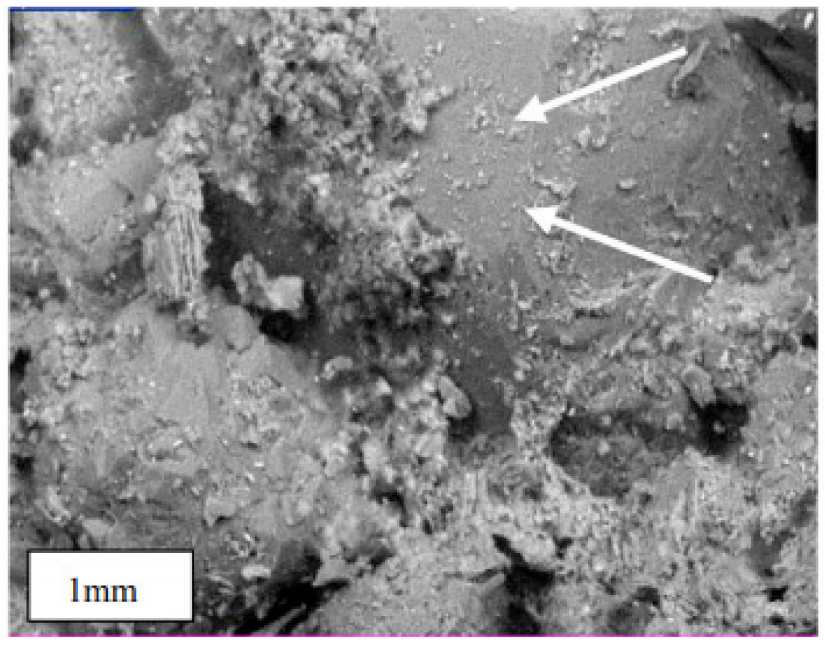

Figure 7. The spread of altered minerals on a sandstone sample post exposure to betaine [50]. 
Wuyep et al. [50] concluded that chemical reactions, adsorption, disintegration/precipitation, and exchange of ions occurred between the industrial liquids and these reservoir core samples, distorting the bonding between minerals of the core samples due to dispersion of disintegrated mineral particles inside the moving liquids [50]. Wuyep et al. [50] neglected the varying physicochemical characteristics of the individual clay species observed-such as booklet kaolinite, platy kaolinite, blocky mixed layer (illite + smectite), or xenomorphic or anhedral mixed layer (illite + smectite)—because the shape and size of particles affects particle-particle interaction, the strength of rock and, ultimately, the extent of formation damage in the sandstone reservoir.

Al-Yami et al. [62] studied the effects of interaction between various water-based fluids and an Unayzah-B sandstone reservoir containing clay on formation damage; they investigated the permeability reduction triggered by the different RDFs $\left(\mathrm{Mn}_{3} \mathrm{O}_{4}\right.$ drilling fluid, $\mathrm{KCl} / \mathrm{CaCO}_{3} / \mathrm{BaSO}_{4}$ drilling fluid, and potassium formate drilling fluid). They observed that although potassium formate drilling fluid has low particle content, $\mathrm{KCl} / \mathrm{Mn}_{3} \mathrm{O}_{4}$ drilling fluid showed the least formation damage compared to the other two RDFs (potassium formate $/ \mathrm{CaCO}_{3}$ or $\mathrm{BaSO}_{4} / \mathrm{CaCO}_{3}$ mud systems). They concluded that the poor performance of filtrate from $\mathrm{KCOOH}$ was because of incompatibility with the pore fluids of the reservoir in Unayzah-B, while that of $\mathrm{BaSO}_{4} / \mathrm{CaCO}_{3}$ drilling fluid was attributed to trapped barite solids inside the core. The main reason for the better performance of $\mathrm{KCl} / \mathrm{Mn}_{3} \mathrm{O}_{4}$ drilling fluid was because of the spherical geometry and minute size of $\mathrm{Mn}_{3} \mathrm{O}_{4}$ solids, which allowed the particles to be removed by the flow of hydrocarbons; however, the authors did not consider the interaction of the drilling fluids with the varying clay minerals present in the Unayzah-B sandstone, which caused permeability impairment; rather, performances were only judged based on the compatibility and sizes of the bridging materials present. In another study, Al-Yami et al. [63] studied the effects of $\mathrm{H}_{2} \mathrm{O}$-based RDFs on invading particles and mechanisms of damage reaction; they investigated the intensity of damage caused by the weighting materials in three different $\mathrm{RDFs}\left(\mathrm{H}_{2} \mathrm{O}\right.$-based $\mathrm{Mn}_{3} \mathrm{O}_{4} \mathrm{RDF}, \mathrm{H}_{2} \mathrm{O}$-based $\mathrm{CaCO}_{3} /$ barite $\mathrm{RDF}$, and $\mathrm{KCOOH} \mathrm{RDF}$ ) used to conduct return permeability tests [63]. They observed that the filtrate from $\mathrm{KCOOH} \mathrm{RDF} \mathrm{did} \mathrm{not} \mathrm{cause}$ migration of kaolinite with booklet-form physiochemical characteristics, and the environmental scanning electron microscopy (ESEM) and energy-dispersive spectroscopy indicated precipitation of potassium chloride within the pore structures of the reservoir (Figure 8).

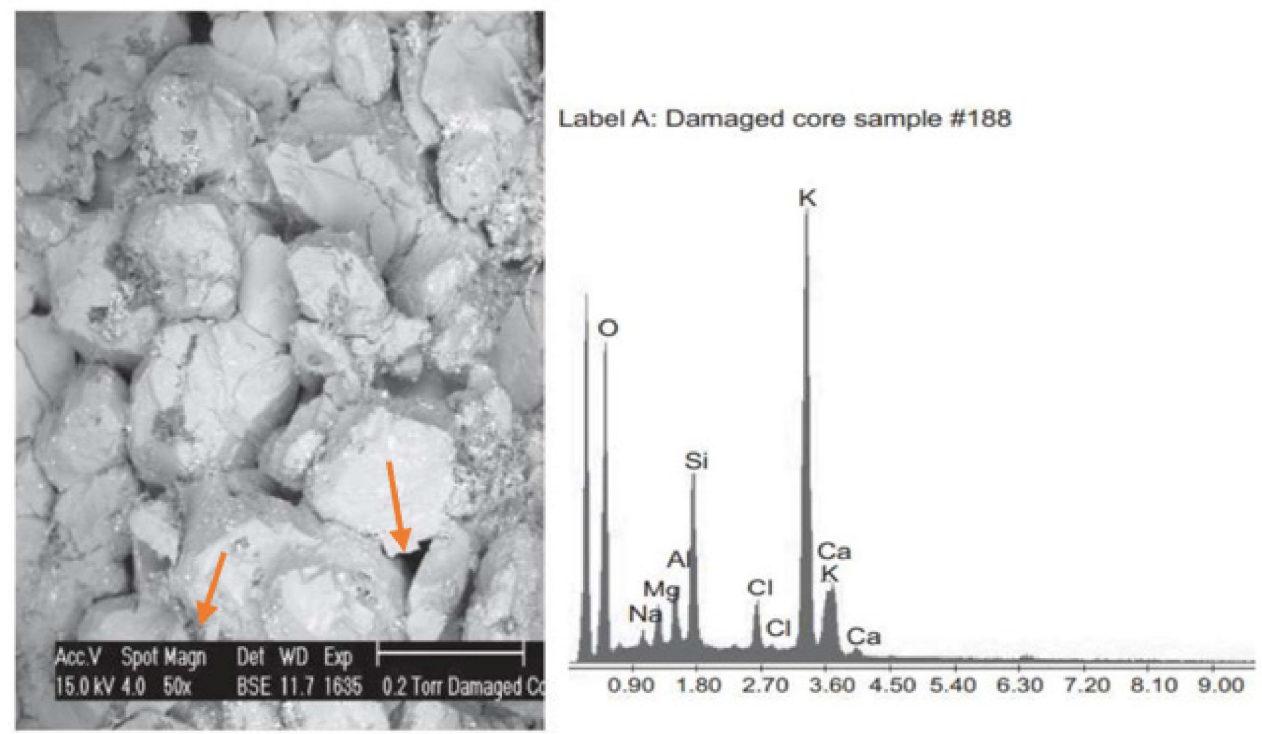

Figure 8. ESEM photomicrograph and EDS analysis showing potassium chloride precipitation within the pore structures of the reservoir [63]. 
Al-Yami et al. [63] only considered one individual species-namely, booklet kaolinite-and did not consider other individual species of clay minerals of varying physicochemical characteristics, such as platy kaolinite, vermicular kaolinite, or blocky kaolinite. It is most often the case for kaolinite to become detached from grain walls and then migrate and flocculate or deflocculate after interaction, before being eroded by drilling fluids.

In a related study, Zhang et al. [64] studied reduction in the permeability control of saline-lacustrine fractured tight oil reservoirs during drilling operations; they observed that the reservoir was composed of a large amount of sensitive clay particles (with the clay content ranging from 5.2 to $30.8 \mathrm{wt}$ \% (18.15 wt.\% on average)); the clay minerals were made up of a mixed layer (illite + smectite) estimated as $2.1 \%$, illite estimated as $9.7 \%$, and chlorite, which was dispersed and subsequently migrated to occlude pore throats after interaction with drilling fluids (Figure 9) [64].

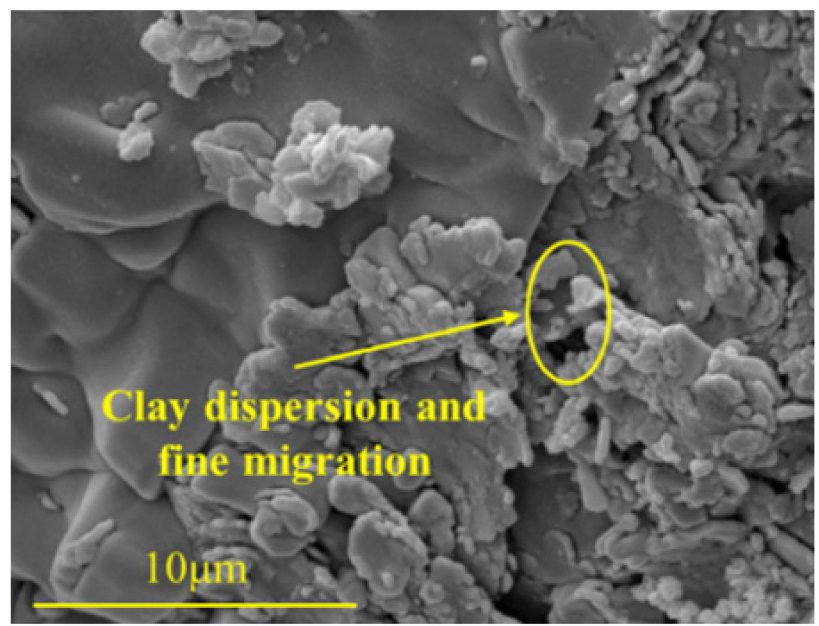

Figure 9. Clay dispersion and fine migration after rock-fluid interaction [64].

Zhang et al. [64] concluded that RDFs can be enhanced with respect to the evolution of fissures typical of the formation, the effect of mineral disintegration on rock properties, and excessive pressure-induced plugging of flow paths [63]. Nevertheless, Zhang et al. [64] - like many other researchers — did not pay attention to the individual clay species in varying clay minerals; rather, clay minerals were treated as a group. Zhang et al. [64] stated that saltwater permeability reduction reactions should be regarded as a crucial damage reaction mechanism during drilling [64]. This supports the idea that high salinity can cause formation damage.

Characterisation of formation damage mechanisms using scanning electron microscopy (SEM) has shown that flocculation or deflocculation of pore-lining clays occurs due to invasion of very high- or very low-salinity RDFs, leading to major occlusion of narrow micropore structures [65]. However, these individual species of clay minerals in terms of the varying physicochemical characteristics (morphology) —for example, booklet, vermicular, or platy-affect the mobility due to particle-particle contact within the pore structures of the reservoir. The shape and size of the varying clay minerals can also influence migration [63].

In similar research about kaolinitic fine migration damage, Hayatdavoudi and Ghalambor [66] studied mitigation permeability reduction induced by kaolinitic species. They carried out return permeability tests and observed that the pre-flow SEM photomicrograph (Figure 10) and post-flow SEM photomicrograph (Figure 11) showed no indications of alteration of kaolinite to smectite; rather, Figure 10 depicts a different kind of clay mineral - that is, the breakdown of platy kaolinite and the appearance of some other forms of clay minerals. 


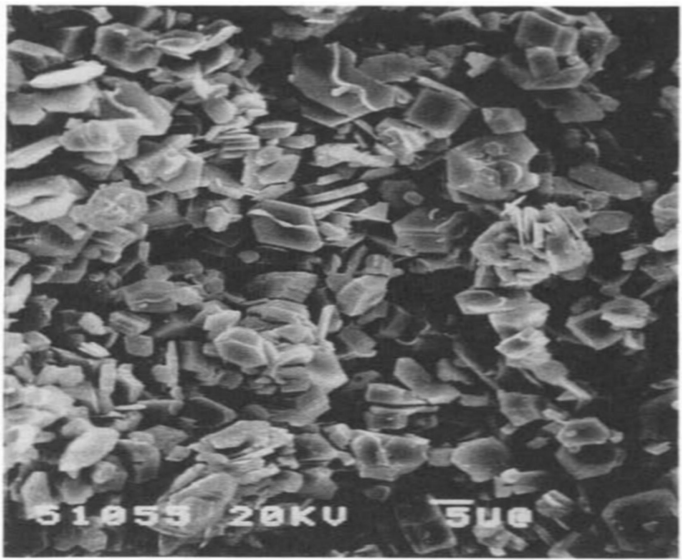

Figure 10. Sandstone core from Tuscaloosa reservoir in pre-flow conditions (note the intact authigenic kaolinite in the pore system) [66].

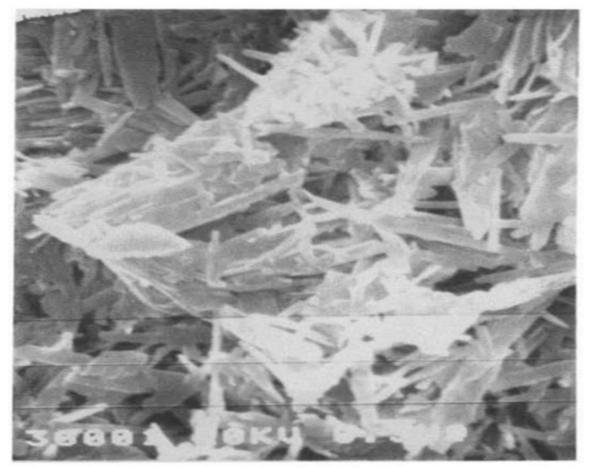

Figure 11. Sandstone core from Tuscaloosa reservoir in post-flow conditions (note-this figure points to the reasons for formation damage) [66].

Hayatdavoudi and Ghalambor [66] concluded that kaolinite clay minerals undergoing a highly oxidative process caused by sodium peroxide could be partially altered to dickite and halloysite. The hypothesis relating to the conditions of change within the same group of clay minerals is correct, and formation damage is not caused by the migration of platy kaolinite mentioned, but by an oxidation process disintegrating booklet kaolinite, and this disintegration can be prevented by buffering the fluid system in order to mitigate the formation of powerful oxidizers [66]. Whenever corrosion, flocculation, and deflocculation of clay minerals occur, they will necessarily be accompanied by fine migration; however, Hayatdavoudi and Ghalambor [66] do not acknowledge the movement of kaolinitic particles as being among the mechanisms leading to reduction in permeability. Nevertheless, they do recognise the varying physicochemical characteristics-platy kaolinite, booklet kaolinite, and the alteration of kaolinite to other forms of the kaolinite group-in agreement with the findings of this study.

Zhao et al. [11] studied permeability-reducing reactions connected with RDFs for producing formations located offshore, by performing analyses of reservoir characteristics and formation damage evaluation using a controlled flow rate to propose a solution for the design of RDFs. Columns of rock samples $2.5 \mathrm{~cm}$ in diameter and 5-6 cm long were obtained from the Huangliu formation, containing unconsolidated siltstone at a depth of $3310-3355 \mathrm{~m}$ and an amount of clay minerals of between 6 and $19 \mathrm{wt} \%$ with large pore throats. They observed that formation damage due to the increase in velocity of flowing liquids was strong, and caused great fluctuation in the permeability values, because the moving fines blocked the main micropore structures or flowed out stochastically with increasing velocity in core samples \#2 and \#3 (Figure 12). They stated that abnormal salt 
concentration levels in reactive fluids were apparent, with very important salinity observed at $40,000-45,000 \mathrm{mg} / \mathrm{L}$ (Figure 13) [11].

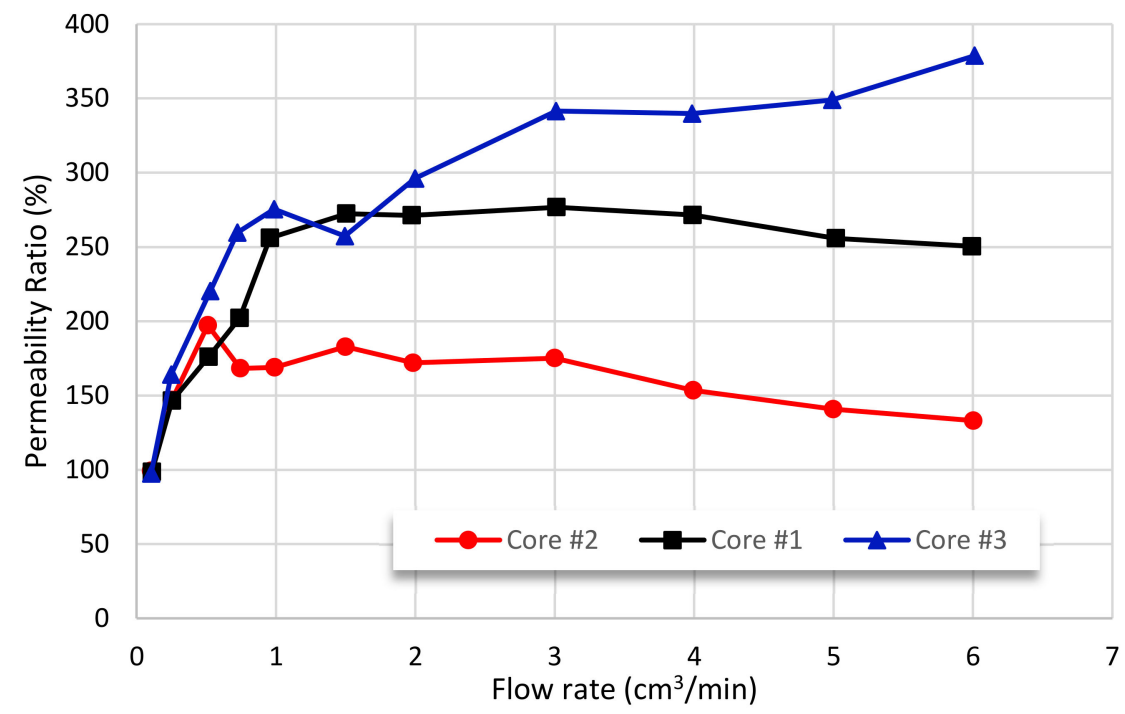

Figure 12. Effect of synthetic formation water flow rate on the permeability of Huangliu sandstone reservoir cores [11].

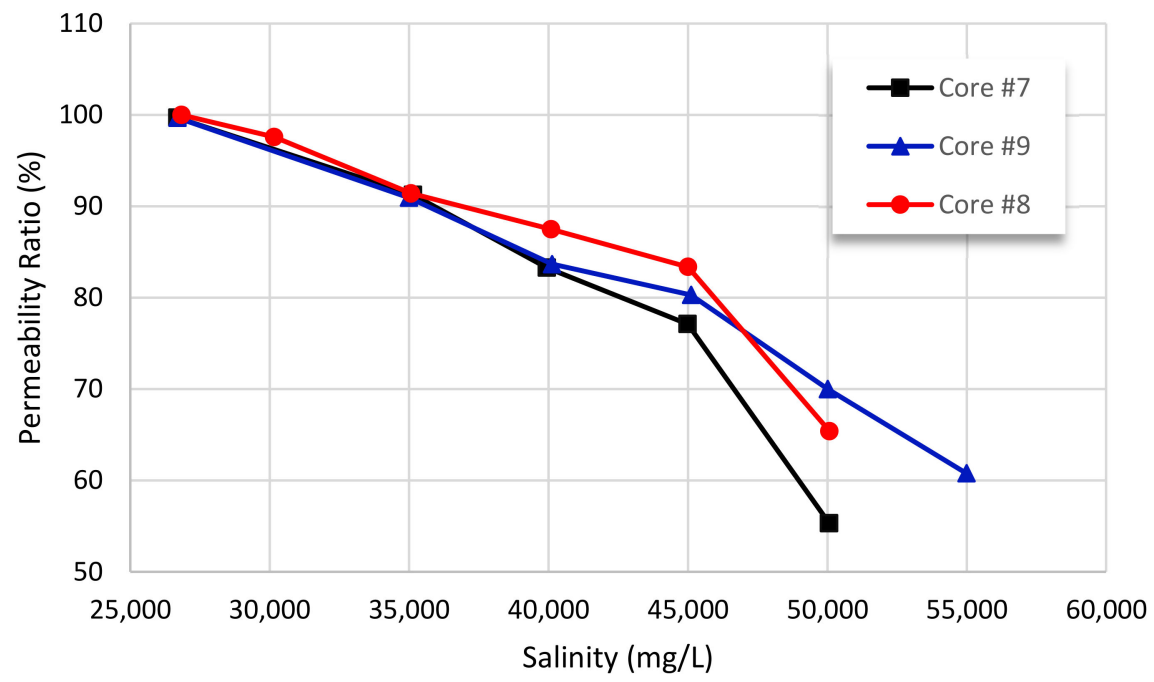

Figure 13. Impact of the salinity of synthetic pore fluid on the permeability of Huangliu sandstone reservoir cores [11].

Zhao et al. [11] concluded that pore throats were occluded by the solid invasion of the sealing particles in the RDFs that were suitable for the deposition of an external filter encrust, but fines were detached from the pore wall. Following the invasion of extremely saline RDFs, clay particles in the producing formation contracted and detached due to the movement of the electrically charged double layer and the clay particles towards one another [11]. These clay minerals migrated and plugged narrow micropore structures due to increased flow rate and salinity [11]. However, Zhao et al. [11] did not emphasise the fact that despite the particle diameter arrangement of the sealing materials used in RDFs, micronized materials that are below $1 \mu \mathrm{m}$ in size are commonly found, which can cause internal damage through the formation of internal filter cakes near surface pores after interaction with the varying clay minerals. The internal filter cakes were very difficult to remove, and caused damage challenges; this is consistent with the findings of Al-Yami et al. [62]. 


\section{Remarks}

The literature reviewed in the section above includes contemporary works carried out in order to improve the technology for formation damage mitigation/formation damage control (FDM/FDC) associated with the challenges presented by clay minerals during drilling and production operations in the petroleum industry. Observations from existing literature indicate that a key to the effective implementation of FDM/FDC technology in the petroleum industry is the design of RDF formulations that have minimal damaging properties near the wellbore area.

This necessitates optimal ionic concentration and $\mathrm{pH}$ for an efficient drilling fluid design. Unfavourable salinity and $\mathrm{pH}$ conditions can lead to formation damage closely associated with clay minerals via mechanisms such as swelling, corrosion, flocculation, and deflocculation of individual clay species. The invasion of filtrate into sandstone reservoirs with varying clay minerals has an adverse effect on the productivity of the reservoir. Authigenic precipitation has been identified as a sixth-order damage mechanism under chemical mechanisms/rock-fluid interactions, which can result from corrosion, deflocculation, flocculation, or migration of individual clay species with varying physicochemical characteristics in sandstone reservoirs with varying clay minerals. Nevertheless, the varying physicochemical characteristics of the individual clay species observed in the clay minerals—such as booklet kaolinite, platy kaolinite, blocky mixed layer (illite + smectite), or xenomorphic or anhedral mixed layer (illite + smectite) — were not considered during the development of the FDM/FDC technology. FDM/FDC technology essentially requires the formulation of minimally damaging RDF. The interaction of RDF with individual clay species in the clay minerals present in the sandstone reservoir must be considered, because the shape and size of particles will affect particle-particle interaction, rock resistance and, ultimately, the extent of formation damage in the sandstone reservoir with varying clay minerals. In the principle of formation damage control developed in recent studies, clay minerals have been treated as a group, and several of the studies that have recognised the varying physicochemical characteristics of individual clay species $[61,63,66]$ —which is consistent with this study - have not properly connected it to the formulation of minimally damaging RDF.

Characterisation of formation damage mechanisms using scanning electron microscopy (SEM) has shown that flocculation or deflocculation of clay minerals covering narrow micropore structures is a result of permeation of RDF with very high or low salt concentration, inducing severe occlusion of narrow micropore structural networks; this is consistent with the findings of Bishop [65]. However, the individual species of clay minerals in terms of the varying physicochemical characteristics (morphology)—for example, booklet, vermicular, and platy-impact migration due to particle-particle contact within the pore structures of the reservoir.

For newly formulated drilling fluids to be accepted by the industry, there would be a need for detailed analysis and assessment not only of the safety implications, but also of the impact on and interaction with the reservoir formation containing varying clay minerals.

\section{Microscopic Examination of Formation Damage}

Extensive petrographic image analysis (PIA) of representative core samples of sandstone reservoirs provides knowledge of the individual clay mineral species encountered [13]. The characteristics of oil-/gas-producing formations, fundamentally influenced by the porosity and permeability of significant formations, are affected by several microscopic features. Examples include the types of the compositional units of clay minerals and binding minerals, the extent of bonding between mineral grains, and the extent of grain size arrangement; in other words, the configuration of mineral fragments and the narrow micropore structure arrangement $[14,67,68]$. Field operations depending on formation damage return permeability testing are particularly reactive to minor alterations of the microscopic features (such as pore-throat size distribution and clay minerals) of oil-/gas-producing formations, as well as their effects on permeability and formation damage [69]. 
In most studies, the extent of permeability reduction has been investigated by core flood testing and measurement of return permeability [70-72]. A major parameter that controls the extent of permeability alteration/damage reaction due to corrosion, deflocculation, and flocculation of clay minerals is the geometric disposition of clay minerals inside the micropore structural network, and with respect to native sandstones this relates to the origins of the clay, including the dimensions and arrangement of the narrow micropore structure. The knowledge of reservoir rocks' microscopic features or properties-especially the occurrence of clay-is crucial in order to predict fluid flow in porous media, minimise formation damage, and optimise productivity. Numerous contemporary techniques are employed to help in interpretation, such as those described in the following subsections.

\subsection{Scanning Electron Microscopy (SEM) and Micro Computed Tomography $(\mu \mathrm{CT})$}

SEM allows the computation of pore openings of small diameter in rocks and enables slight observation of 3D micropore structural networks [73]. SEM can compute micropores measuring between $5.0 \times 10^{-1}$ and $5.0 \times 10^{3} \mu \mathrm{m}$ [73]. SEM is a highly pragmatic technique for determining dimensions and describing microporosity [73]. The effort needed to analyse so many samples with different structures and compositions renders SEM an impractical solution for finding micropores of larger diameter that need to be sealed throughout drilling operations [73]. SEM with a magnification range of $\sim 100-10,000 \times$ can be used to visualise changes in naturally existing minerals and permeation of RDFs-including sealing additives from drilling and workover fluids-depicting dissimilarities and assessing the performances (such as retention) of RDFs [74].

$\mu \mathrm{CT}$ offers the opportunity for the assessment of 3D micropore configuration and micropore structural network analysis [73]. Samples with very small diameters are used to realise a submicron resolution, and higher resolution requires more time to acquire the images - and vice versa [74]. The entire cost and time needed for $\mu$ CT imaging are controlled by the operational settings parameters [74]. A resolution of 10-15 $\mu \mathrm{m}$ can be achieved for images of reservoir rocks with a diameter between $25.4 \mathrm{~mm}$ and $38.1 \mathrm{~mm}$ and a length of up to $50 \mathrm{~mm}$ [74]. However, it is necessary to consider the volume of data generated, because images that are initially 10-20 GB in size could increase to $~ 60-80$ GB after processing using modelling software, and storage of the data in caches may become challenging [74]. The images acquired with $\mu \mathrm{CT}$ scans have better resolution compared with those of CT scans [74]. Hence, $\mu$ CT scans are widely used in the study of reservoir samples, because in terms of micropore configuration and alteration of mineralogy they give detailed information about individual mineral grains and the micropore structural network [74]. Visualisation of micropore features in the course of formation damage mitigation and control is very easy with the use of $\mu \mathrm{CT}$ compared to SEM, thin-section analysis, and other techniques [74]. Furthermore, $\mu \mathrm{CT}$ is a non-destructive technique.

\subsection{X-ray Diffraction (XRD)}

Chemical analysis of clay minerals that has not been supported by XRD techniques gives scant information about the clay minerals present in reservoir rocks, and this can be very deceptive [75].

XRD is initially used to investigate the mineralogy of rock samples and give sufficient data on the clay (less than $2 \mu \mathrm{m}$ ) fraction; this is a major issue in terms of similarity [74]. The XRD method utilises pulverised rock fragments that have been cleansed, micronized, and weigh $\sim 10 \mathrm{~g}$, meaning that important micropore features in rock samples are destroyed during XRD analysis [74]. Carrying out XRD investigation after formation damage analysis may show important changes in mineralogy (especially disintegration of minerals binding grains of rock together); however, alterations in the spatial disposition of minerals cannot be revealed by this technique [74]. Therefore, this technique can be very helpful during the study of untreated minerals [74]. 


\subsection{Thin-Section Analysis}

This method uses rock fragments that are $\sim 30 \mu \mathrm{m}$ in thickness. This allows for the visualisation of minerals at a magnifying power of $2-50 \times$ magnification of the grains present and micropore structures [74]. This approach has been utilised in the course of picking up information on the whole variation of mineral content with broad alteration of rock fragments [74]. This method destroys rock fragments, but is unidimensional in terms of the data provided on the sample; hence, it is limited in terms of what it can visualise [74].

\section{Commonly Used Microscopic Characterisation Techniques}

Micro-scale investigations of formation damage have been carried out by some studies, and recommendations for the enhancement of RDF have been put forward [68]. Fang et al. [76] studied alkali reactivity damage reactions of clay deflocculation and movement; they performed water-blocking experiments (WBEs) using core samples from a clay-enriched Nanyang Sag sandstone reservoir, and with the aid of nuclear magnetic resonance imaging (NMRI) they observed that following alkali reactivity damage, the brilliance in Figure 14a was higher than in Figure 14b [76]. This is an indication that many micropore structures are not plugged with clay fines in Figure 14a, while in Figure 14b there is an indication of micropore structures that have been plugged with clay fines, because clay fines have undergone detachment and migration from micropore walls in Figure 14a, and are suspended in damaging drilling fluid, while some of the detached clay fines cover the narrow micropore structures with large diameters in Figure 14b [76]. Therefore, flow paths for fluids were plugged, and the permeability of the core was reduced [76].

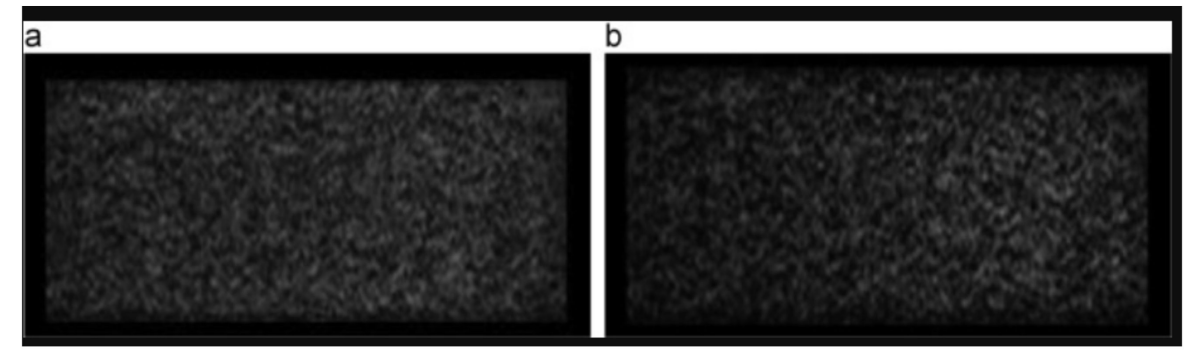

Figure 14. Nuclear magnetic resonance images of core 94-2 from the clay-enriched Nanyang sandstone reservoir: (a) $\mathrm{pH}=7.0 ;$ (b) $\mathrm{pH}=13.0$ [76].

Fang et al. [76], in conclusion, proposed the use of NMRI as an evolving investigational method for the measurable assessment of reactive clay minerals [76]. Invasion of filtrate and solids from the RDF into zones of a reservoir section is closely connected to the micropore structural network of the sandstone reservoir and the major flow paths within it, which are influenced to a greater extent by these clay minerals. Therefore, characterisation of the micropore network should precede any meaningful measurement of pore size. Pore-throat size is not a linear quantity. Pore-throat diameter arrangement plays a very important role in permeability reduction reactions due to the migration, flocculation, and swelling of clay minerals [61]. The general notion in the field of petroleum reservoir engineering that the micropore structures are simple linear spaces between mineral particles that can be sufficiently modelled with sand packs or aloxite disk proxies may be misleading with regard to sandstone reservoirs with varying clay minerals [73]. Microscopic pore-throat features can vary in both shape and distribution in a particular reservoir. Bin et al. [77] studied the configurational arrangement and texture of micro-scale pore networks in tight sandstone reservoirs of the Triassic Yanchang Formation, Ordos Basin; they carried out characterisation of core samples from Yanchang sandstone reservoir using different scales for the 3D computer tomography (CT) scan. They observed that the Yanchang sandstone reservoir can be divided into three groups in consideration of the amount of micropore features, geometry, and arrangement (Figure 15) [77]. 

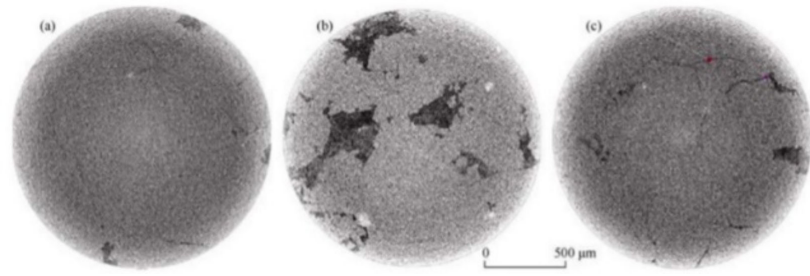

Figure 15. Two-dimensional $\mu \mathrm{CT}$ scans, Yanchang sandstone reservoir [77].

Bin et al. [77] concluded that microporous structural tubules with excellent connectivity formed channels that connected to other large microporous structural tubules, but separated spherical nanopores with poor networks acting only as reservoir areas (Figure 16) [77].
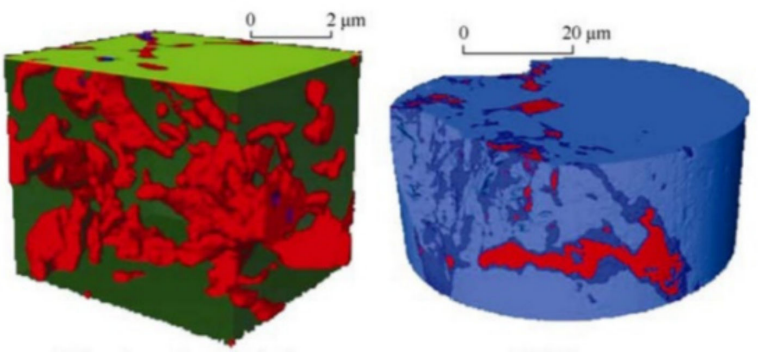

Figure 16. Micro-CT images of pore-throat interconnectivity in the Yanchang sandstone reservoir [77].

Attributes of micropore systems and flow paths can be used to determine the size distributions of particles in the arrangement of sealing materials utilised for improving the formulation of minimally damaging RDF [73]. Therefore, optimised FDM/FDC technology should include the determination of narrow micropore structural size arrangement; this is consistent with the findings of Bin et al. [77]. The most important features of micropore structural networks include the dominant flow channels in the rocks, the dimensions, and the distribution and connectivity of pore throats. The bridging particles' size distribution in RDF can be optimised using thin-section analysis, based on the diameter of the micropore structure and its arrangement. Contrary to the report of Rezaeizadeh et al. [78] that thin-section analysis is primarily utilised in preparing for other analytical techniques, in two separate studies He and Stephen [73] carried out research on the selection of optimal sealing particle size arrangement in RDFs and permeability reduction, while Liang et al. [79] conducted research on the quantification of permeability reduction caused by the crosslinked gel in a tight gas-producing formation. These two studies show that thinsection analysis can be used for an optimised FDM/FDC technology. He and Stephen [73] presented two different results on thin-section analysis related to bridging particle selection (Figures 17 and 18); they observed that the bridging particle size distribution in Figure 17 was optimised based on micropore size, and no major quantity of particles invaded the rock material [73]. In Figure 18, optimal particle size was not considered in the RDF based on the diameter and arrangement of the micropores, leading to micronized particles (dark or brown material) from RDF invading deeper parts of the rock material, and the smallest microporous structural connections were also plugged [73].

Liang et al. [79] showed different results of thin-section analysis related to experimental evaluation of permeability reduction caused by the crosslinked gel in a tight gas-producing formation (Figure 19); they observed that the microscopic distribution of minerals was very complicated in the thin-section photomicrograph, and concluded that such heterogeneity of minerals can cause additional formation damage [79].

Additional formation damage can result from the interaction of drilling fluids with varying clay minerals; this is consistent with the findings of Liang et al. [79]. Among the adverse effects of the interaction between drilling fluids and clay minerals are corroded edges and alteration of native morphology; this gives rise to deflocculation, flocculation, and fine migration. 

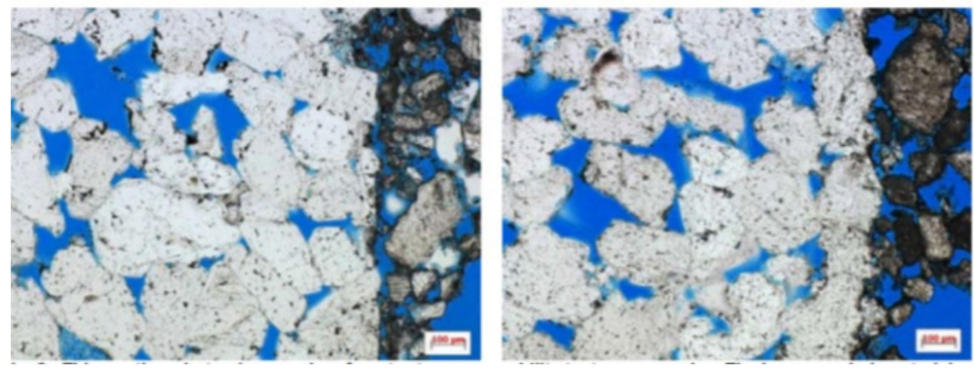

Figure 17. Photomicrograph showing thin-section analysis results for post-formation-damage testing of rock material using drilling fluid with optimised bridging particles. The brown or dark substance on the right side of each micrograph is filter cake [73].
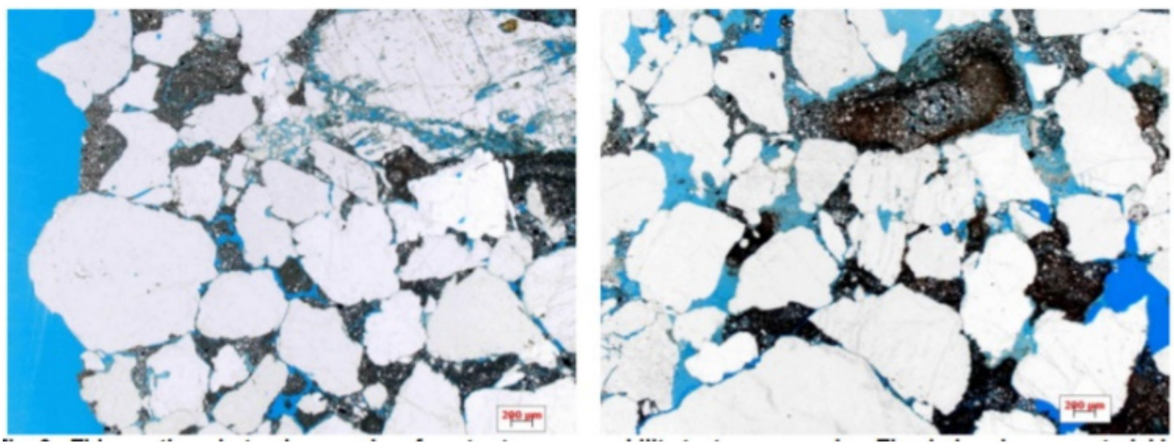

Figure 18. Photomicrograph showing thin-section analysis results for post-formation-damage testing of rock material using drilling fluid with non-optimised bridging particles. The dark or brown substances are solid particles from drilling fluid [73].

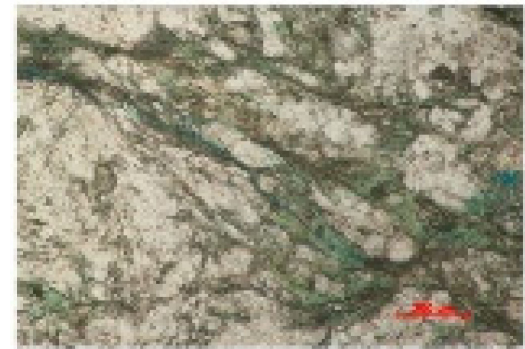

(a) Rare fractures

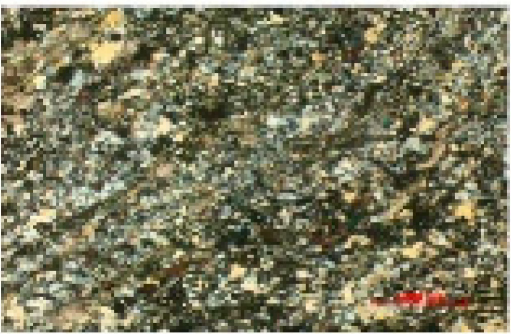

(c) Biotite quartz sheet

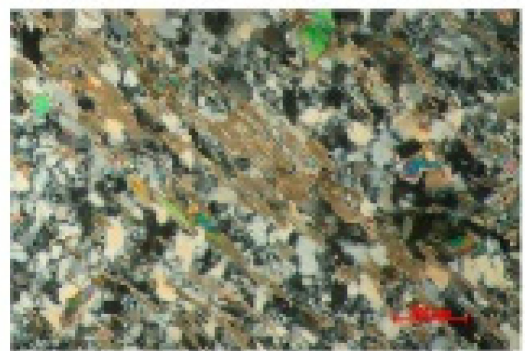

(b) Black mica

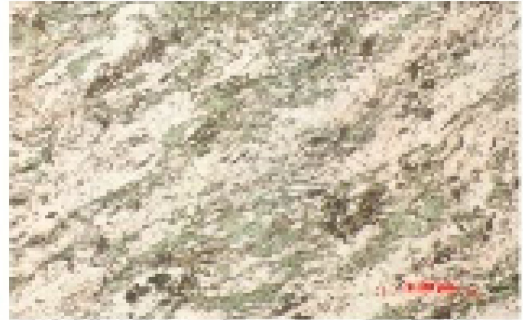

(d) Foliated structural seum

Figure 19. Thin-section photomicrograph of sandstone core from the Jilin oilfield showing mineral heterogeneity: (a) Biotite quartz sheet and (b) Foliated structural seam [79].

Therefore, a robust evaluation of formation damage should involve the simultaneous assessment of reservoir rock-fluid interaction at the wellbore face, inner wellbore face, formation face, and inner formation face (Figure 20). This can be achieved with a combination of micro computed tomography $(\mu \mathrm{CT})$ and SEM/EDS analyses. 


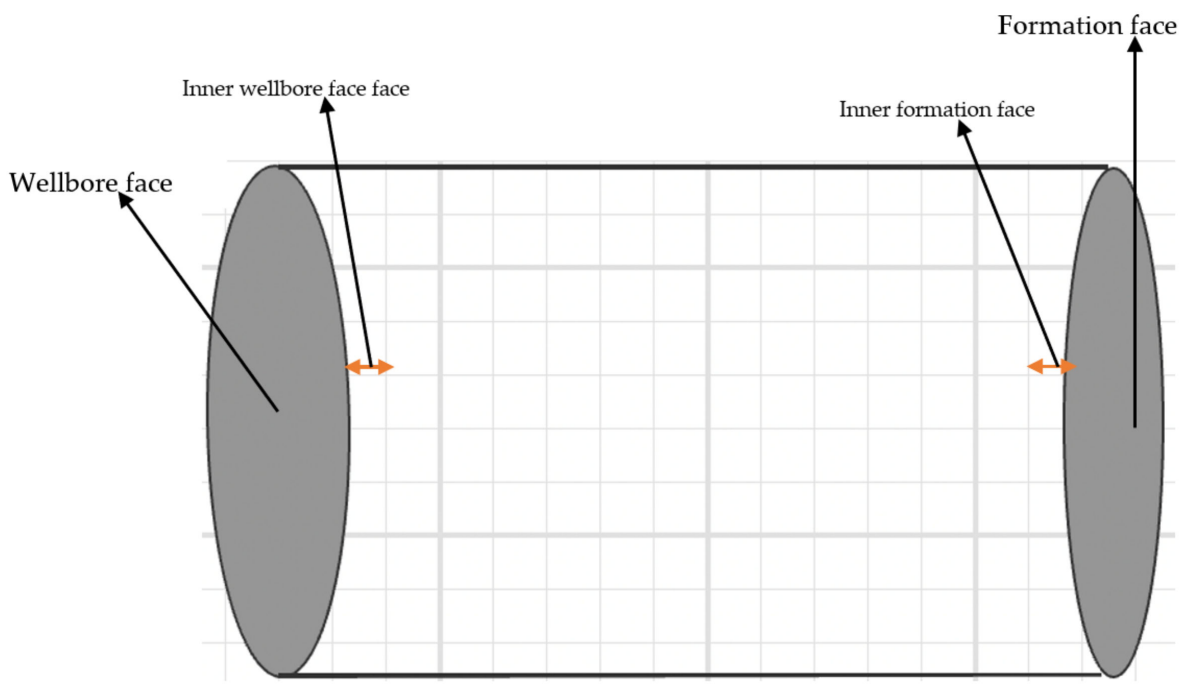

Figure 20. Areas of a sandstone core sample showing the wellbore face, inner wellbore face, formation face, and inner formation face.

Wilson et al. [80] documented an interesting observation about the evaluation of effluent from reservoir rock material, and indicated that illite was more plentiful than kaolinite, whereas kaolinite was described as more abundant than illite in the untreated core of the sandstone hydrocarbon reservoir. It was concluded that a reasonable explanation for this result could be that the illitic clay minerals were able to move more easily than kaolinitic clay minerals, and preferentially migrated inside the rock in reaction to moving water [80]. Wilson et al. [80] did not consider which of the individual clay species (e.g., platy, vermicular, blocky) had been eroded, deflocculated, flocculated, or migrated. It is crucial to pay attention to these varying physicochemical characteristics of individual clay species in order to develop FDM/FDC technology for protecting against productivity impairment in sandstone with varying clay minerals.

Elsewhere Zhou et al. [81] carried out research on clay swelling and its application in formation damage, and showed that clay swelling could possibly be controlled by temperature and differential pressure between the overburden pressure and pore pressure; They concluded that the effect of temperature on clay swelling is insignificant, but the higher the differential pressure, the less the effect of clay swelling [81].

In another study, Baker et al. [82] investigated illite/smectite freshwater sensitivity in sandstone reservoirs using ESEM, and concluded that smectite-rich (illite + smectite) mixed-layer clay may swell to form a gel that ultimately reduces permeability, or may undergo indirect morphological alterations that may not cause formation damage, but illite-rich (smectite + illite) mixed-layer clay will not swell and cannot cause formation damage. Baker et al. [82] did not mention which type of illite-smectite was attackedperhaps blocky, xenomorphic, or anhedral.

In two separate studies, Abass [83] carried out his research on the wellbore instability of clay-rich rock, while Santarelli [84] studied the swelling of clay-rich rock. They both showed that repressive materials such as potassium chloride $(\mathrm{KCl})$ are normally added to RDFs in order to inhibit the swelling and hydration of clay minerals in oil and gas sandstone reservoirs. They concluded that the presence of certain clay minerals in the formation prevents these materials from displaying inhibitive effects, instead increasing dispersion $[83,84]$. The strength of kaolinite-rich rock decreases in effect, resulting in deflocculation during contact with $\mathrm{KCl}$ due to the chemical transformation of kaolinitic minerals $[83,84]$.

Wilson et al. [80] reported that Mering [85] carried out a study on electron-optical investigation of clays, and observed that the dispersibility of individual montmorillonite samples could be very much different from one another even though they are of the same 
smectitic family of clay minerals; for example, montmorillonites from Wyoming and Camp Berteaux have shown varying dispersibility trends. Mering [85] concluded that while the Wyoming montmorillonite was present in comparatively large particles $(0.2$ to $0.5 \mu \mathrm{m}$ in diameter) clustered face to face in a structural sheet-like manner, the Camp Berteaux montmorillonite was composed of extremely micronized solids approximately $1.0 \times 10^{-5} \mathrm{~mm}$ wide, aggregated in an end-to-end fashion [80]. The particle-particle interaction affects the aggregation of these clay minerals and, ultimately, influences the extent of the varying physicochemical characteristics of individual clay species that are altered in the sandstone reservoir with varying clay minerals. However, we believe that oil- and gas-bearing formations' interactions with drilling fluids-leading to alterations of the physicochemical characteristics of the individual clay species—can be better evaluated in close detail when $\mathrm{SEM} / \mathrm{EDS}$ is combined with $\mu \mathrm{CT}$, using a technique called difference mapping.

Green et al. [74] carried out research on the interaction of RDF with core samples from the South Morecambe gas field in the UK's East Irish Sea; they performed a return permeability test on sodium/potassium- and sodium-based drilling fluids, and improved the interpretation of the RDF-related formation damage laboratory tests using the difference mapping technique. Green et al. [74] stated that whereas separate $\mu \mathrm{CT}$ slices cannot provide the resolution of SEM or thin-section analysis, a difference mapping technique was able to capture a large quantity of data on the texture and density of untreated (B) and treated (A) core samples (Figure 21) [74]. Green et al. [74] reconstructed datum C in Figure 20 as a three-dimensional datum using computer applications via a procedure called volume rendering, shown as a two-dimensional output on a computer screen [74].

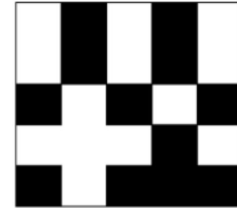

A

(After)

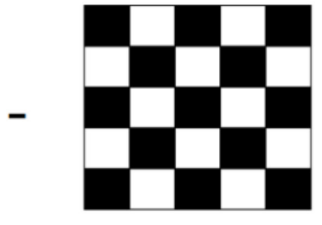

B

(Before)

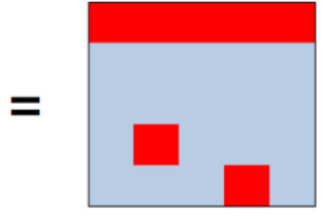

C

(Change)

Figure 21. Example of difference mapping method used for a 2D 5 by 5 grid [73].

Green et al. [74] observed that the alterations within the wellbore face have a strong presence in the region of the filter encrust, as well as in the regions of greater than $\sim 1 \mu \mathrm{m}$ deep into the wellbore face [73]. No major alterations occurred beyond the regions deeper than 1-2 $\mathrm{mm}$ into the wellbore face [74]. They noted that minor differences could be observed between samples, such as the depth and form of the residue of the filter encrust in the 3D data (Figure 22a), and many pores being filled with retained filtrate in 3D data after the return permeability test (Figure 22b)

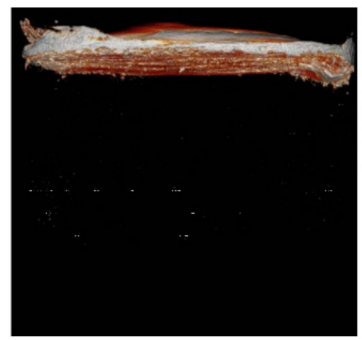

(a)

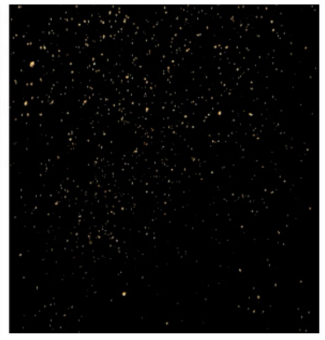

(b)

Figure 22. Images of the difference mapping method used for $2 \mathrm{D}$ renderings of $3 \mathrm{D}$ information -(a) filter encrust deposited with random alteration within few about $1 \mathrm{~mm}$ deep into the rock material (b) permeation of RDF into micropore structural network [74]. 
Green et al. [74] concluded that the $\mu \mathrm{CT}$ technique, when combined with SEM evaluation, revealed that damage reactions have a stronger presence around the regions of the filter encrust and in regions beyond a few microns $(\mu \mathrm{m})$ into the rock material, although random alterations a result of fluid permeation-including mobilization of clay particles-occurred at greater depths in most core samples (Figure 23).
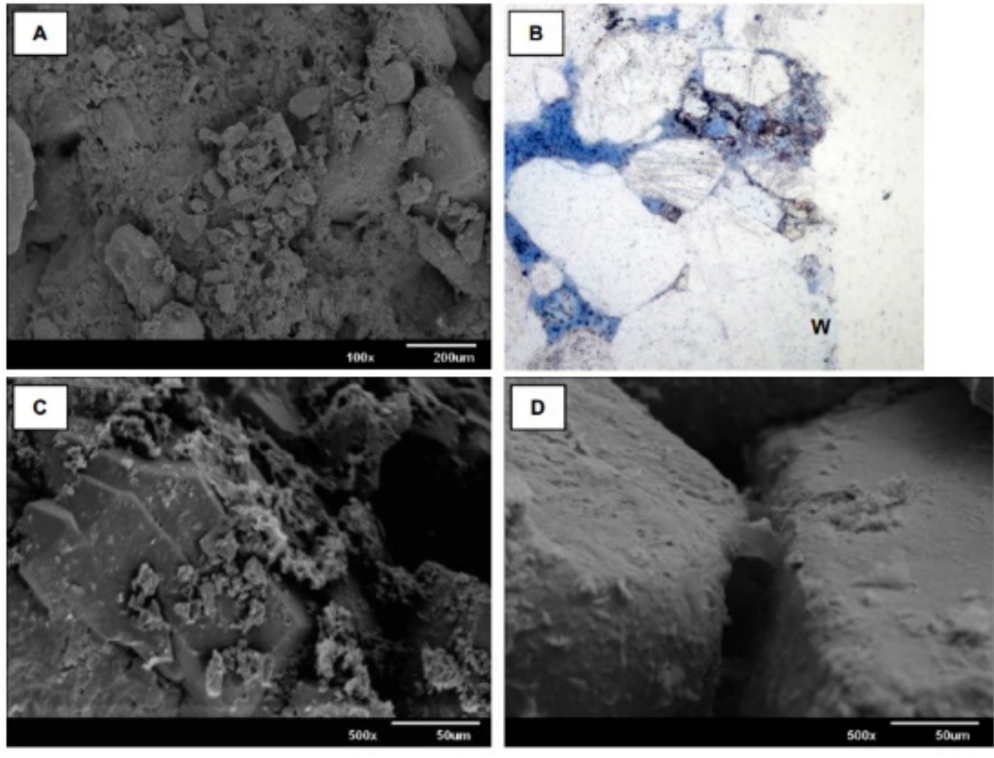

Figure 23. SEM photomicrographs of core samples from the South Morecambe gas field in the UK's East Irish Sea after permeability testing using sodium/potassium-and sodium-based drilling fluids: (A) residue of encrust observed in the sample; (B) W indicating alterations a few mm deep into the wellbore face; (C) randomly emplaced encrust and filtrate a few microns deep into the rock material; (D) dense mineral walls indicating the presence of filtrate [74].

The difference mapping technique is a very valuable tool for evaluating the intensity of alterations in permeability due to rock-drilling fluid interaction, especially in sandstone reservoirs with varying clay minerals.

\section{Remarks}

The studies reviewed in the preceding section include recent works on FDM/FDC technology that utilise advanced evaluative methods in considerations of permeability estimation, depletion of pressure, and information on rate of filtration. These are not sufficient to comprehend the formation damage mechanisms due to corrosion, deflocculation, flocculation, and migration of clay minerals. The individual species of clay minerals and their varying physicochemical properties have not been considered during the formulation of drilling fluids; rather, clay minerals are most often treated as a whole or a group. We believe that kaolinite is present in virtually all sandstone reservoirs in varying physicochemical forms, because it exhibits both the typical polygonal booklet morphology and vermicular morphology, which is consistent with the findings of Baker [80]. Individual platelets of kaolinite may be as large as $30 \mu \mathrm{m}$ across the pore throat, and sometimes show corroded edges and alteration of native morphology after interaction with drilling fluids. The microscopic process of formation damage mechanisms begins with the alteration and corrosion of clay minerals of varying physicochemical characteristics (booklet, xenomorphic, anhedral, vermicular, etc.). Alteration and corrosion fracture these individual clay species, giving rise to minute fragments and fines, and causing flocculation and deflocculation formation damage mechanisms.

Therefore, different processes connected with clay mineral-drilling fluid interaction are the causes of different formation damage mechanisms in sandstone hydrocarbon reservoirs with varying clay minerals. Hence, a robust evaluation of formation damage should involve 
the simultaneous assessment of reservoir rock-fluid interaction at the wellbore face, inner wellbore face, formation face, and inner formation face. The difference mapping technique and SEM/EDS tool can be used for this purpose.

The mechanisms of formation damage associated with varying clay minerals are not yet fully understood, which is consistent with the findings of Wilson et al. [80] that it is unknown to date in the petroleum industry whether the formation of gel from smectitic clay minerals would occur at elevated temperature and pressure conditions of oil-/gasproducing formations. Therefore, using the difference mapping technique together with SEM/EDS can help to characterise damage mechanisms in sandstone reservoirs of varying mineralogy. Furthermore, improvement in the performance of newly formulated drilling fluids in the industry would require detailed analysis and assessment of not only the challenges presented by clay minerals, but also the impact on and interactions of the individual clay mineral species with respect to the drilling fluids' design.

\section{Mitigating Formation Damage through the Design and Selection of Drilling Fluids}

Drilling fluids are combinations of solid materials as additives in varying concentrations present as non-continuous forms dispersed in a constant liquid form [86]. Drilling fluids, which represent $25-40 \%$ of the cost of petroleum-drilling operations [87], should be straightforward to use, low-cost, and harmless to the environment. Drilling fluids are designed to achieve different operational objectives; these include cooling the drill bits, helping to clean the holes of drilled wells by transporting drill cuttings to the surface while maintaining wellbore stability, and preventing the invasion of formation fluids into the wellbore by creating an ultralow-permeability layer (called a filter encrust) on the walls of the wellbore. Santos and Perez [88] posited that formulating optimal sizes and arrangements of bridging materials is the first step in making a minimally invasive and minimally damaging RDF. Contrary to Santos and Perez [88], the challenge with specifying requirements for minimally damaging fluid could be regarded as a bargain between high filtrate invasion into the subterranean reservoir when using an RDF without solids-which can disturb the equilibrium within the pore structure, including mobilization of fines-and the occlusion of perforations and gravel packs when using an RDF containing solids [10].

Minimally damaging drilling fluids can be designed to prevent micronized particles and the liquid phase of RDFs from penetrating into the reservoir section, by using solids in the RDF to create an effective filter encrust on the walls of the subterranean reservoir, with shallow invasion of micronized particles and the liquid phase of the RDF $[10,89]$.

Much effort has been put into the development of appropriate particle size distributions for bridging materials needed for sealing pore throats [89-92]; however, there are conflicting opinions on the subject concerning optimal size range distribution requirements with respect to the specific micropore-throat size arrangement of a sandstone reservoir.

Abrams [93] stated that "drilling fluid should contain at least $5 \%$ Vol. of the bridging material" [93]. Furthermore, the $\mathrm{D}_{50}$ particle size of the sealing additive must be greater than or equal to one-third of the mean pore size of the production zone [93]. Abrams [93] utilised a pack column of sand to represent the pay-zone, thereby treating the pore-throat network as a linear quantity, and did not consider the complexity of pore-throat size distribution in the micropore network of an actual sandstone reservoir. In a related study, Smith et al. [94] studied the development and modifications of drilling fluids' design in order to reduce formation damage in quartz arenite sandstone; they performed particleplugging apparatus tests at an elevated temperature of $93^{\circ} \mathrm{C}$, using $150 \mu \mathrm{m}$ aloxite disks to represent the quartz arenite Mirador Formation with a very low clay content in the Cusiana field in Colombia. They observed that even without sensitive clay minerals, several of the observed damage mechanisms could not be associated with quartz arenites; still, damage reactions due to drilling operations were noticeable, and they concluded that in order to mitigate against such damage reaction mechanisms, the FDM/FDC technology must use $D_{90}$ rather than $D_{50}$ as the optimised size of sealing additive distribution. More attention should be redirected to the evaluation of the diameter and arrangements of micropores 
in sandstone reservoirs, so as to apply the concept of Smith et al. [94] to actual reservoir formation. The micropore structural networks in actual reservoirs are the consequence of diagenetic processes that took place over millions of years ago, and these pore throats were also a part of various stratigraphic processes that have influenced their connectivity. Therefore, description of the micropore structural networks of representative core samples, along with the knowledge of suitable interpretative techniques for the determination of the diameter, arrangement, and limitations of micropore structures, will be key to the appropriate evaluation of the size of solids to use in FDM/FDC technology.

An ideal packing theory (IPT) has also been put forward as a solution for forming an effective filter cake on hydrocarbon-bearing formations [95]. The "ideal packing" can be defined as a complete particle size distribution that can effectively bridge all pore openings, including the pore openings that are a result of the invading bridging materials [89].

The rule posits that optimal sealing is achieved if the percentage of the cumulative volume of the bridging material versus the $d^{1 / 2}$ gives a straight-line plot in arithmetic coordinates, where $d$ is the particle diameter (in $\mu \mathrm{m}$ ) [89]. By using the $d^{1 / 2}$ rule, different bridging materials are plotted in this way on the same graph to illustrate the many types of available products in the oil and gas industry for bridging sandstone reservoirs [89-92].

The IPT technique is largely dependent on measurement of the mean pore size computed from permeability by finding the square root of the permeability (in millidarcys) [96]. We believe that an accurate characterisation of the pore-throat size of reservoir sections with varying clay minerals, which include wider pore-throat size targets, is very necessary during the design of bridging particle distribution, since micropore-throat size arrangement in most production zones is not a linear quantity.

Another important bridging theory has been put forward by Vickers et al. [90]; this theory postulates that the bridging particle distribution must fulfil the following requirements in order to minimise permeation of RDF into the production zone: the diameter of the sealing additives in D90 should be equal to the mean micropore size, the diameter of the sealing additives contained in D75 should be less than two-thirds of the mean micropore throat, the diameter of the sealing additives contained in D50 should be equal to one-third of the mean micropore throat [90], the diameter of the sealing additives in D25 should be equal to one-seventh of the mean micropore throat and, finally, the diameter of the sealing additives in D10 should be equal to the smallest micropore throat in the pore structural network [90].

In the Schiehallion oilfield in the North Atlantic Ocean, west of Shetland, owned by BP, the drilling programme involves the use of drilling fluids that have resulted in a production rate greater than $6 \mathrm{MBOPD}$. After the drilling fluid was designed using bridging particle distribution based on Vickers' stipulated D90, D75, D50, D25, and D10 target fractions, it was documented that $90 \%$ return permeability was recorded in the course of the formation damage evaluation of this drilling fluid on rock materials obtained from the production zone, and field results from the drilled well showed a production rate of 12.5 million barrel of oil per day (MBOPD) [90].

Contrary to the report of Vickers et al. [90], Fleming [97] carried out a field study on the importance of damage reaction for 15 oil wells completed in a low-pressure sandstone production zone located in the Oseberg Formation, Norway, without bridging particles. Fleming [97] observed that the use of drilling fluids formulated without sealing materials for these 15 wells in the Oseberg Formation led to unanticipated results, with the absence of formation damage reactions due to filtration loss in the 15 completed oil wells Fleming [97] concluded that the Brent reservoir sections in the Oseberg Formation were unsusceptible to damage reaction due to filtration loss, despite being depleted [97].

Between 1992 and 2020, drilling fluids that are not laden with solids have gained increased prominence in the industry as FDM/FDC measures for damage reaction due to invading particles, and many researchers (e.g., [12,97-99]) have presented their opinions concerning the use of drilling fluids with few or no additives for use as RDFs. However, it is equally significant to manage anticipated formation damage challenges in reservoirs 
with varying clay minerals, because individual clay mineral species interact with drilling fluids of varying formulations in a variety of ways, giving rise to filter cakes of varying permeability and thickness.

The filter encrust can decrease the amount of filtration loss into the production zone [100,101]. Therefore, optimal well productivity with minimal formation damage to the reservoir and safe drilling and completion operations is dependent on the performance of the drilling fluids [102].

Bleier [103] studied the broadly diverse behaviour of different drilling fluids formulated from different chemical additives, and observed that no drilling fluid is suitable for all situations; hence, drilling fluids are selected based on numerous factors, such as safety, evaporite zones, high-temperature high-pressure (HTHP) application, environment, loss zones, shale problems, well trajectory, and economics. The nomenclatures of drilling fluid varieties in most cases are formed by combination of one or more of the descriptors in Table 2 [103].

Table 2. Physical properties of different drilling fluids containing varying chemical additives [102].

\begin{tabular}{cccc}
\hline Base Fluid & Dominant Cation & Physical Characteristics & Distinguishing Additive \\
\hline Freshwater & Sodium & Mud weight & Lignosulfonate \\
\hline Seawater & Potassium & Fluid loss & Lime \\
\hline Saltwater & Calcium & Viscosity & Gypsum \\
\hline Native brine & Other & Other & Salt \\
\hline Saturated water & & & Polymer \\
\hline Diesel oil & & & Lignite \\
\hline Mineral oil & & Specialty product \\
\hline
\end{tabular}

Abduo [104] compared the effects of utilising water-based mud containing carbon nanotubes and oil-based mud in HTHP fields; an alternative system for preventing clay mineral swelling and deflocculation challenges would be to use an oil-based mud (OBM) system. However, due to environmental concerns, OBM systems are prohibited in Nigeria, the United Kingdom, the USA, the Netherlands, Norway, Saudi Arabia, Qatar, and various European countries, where notable exploration and production operations are currently ongoing [104].

RDFs, also sometimes called drilling fluids, can be utilised in the drilling of hydrocarbonbearing formations or pay-zones $[10,105]$, while completing fluids are utilised for completing and workover operations [105]. Drilling fluids are specially formulated to optimise the productivity index of the producing well [10,105-107]. Currently, in the petroleum industry, the use of clear, heavy brine to drill the reservoir section is becoming very popular [105].

Sangka and Budiman [108] reported that the use of clear, heavy, inorganic brine based on lithium, sodium, silver, rubidium, caesium, or francium phosphate resulted in a significant reduction in non-productive time (NPT) and minimal and substantial increases in the performance of completion fluids in exploration wells named KRE-I and BOP-I, respectively, in Indonesia [108]. Svendsen et al. [109] reported that, among other benefits, the use of the same formate brine system for drilling, completion, and production operations in pressure-reactive production zones containing loose sandstone in the Gullfaks Field, located in block 34/10 in the Norwegian sector of the North Sea, has resulted in economic benefits relating to the cost of maintaining rig equipment and other operating expenditures, along with increased production-recorded as $6 \%$ with regard to the total drilling operating expenses [109].

\section{Remarks}

The studies discussed in the above section have shown that researchers have neglected very crucial aspects in the effective implementation of the principles of FDM/FDC tech- 
nology, such as formulating drilling fluids specifically for kaolinitic sandstone reservoirs, or formulating drilling fluids specifically for kaolinitic and mixed-layer (illitic + smectitic) sandstone reservoirs. OBM contains heavy polymers that are made up of polar and nonpolar ends, which can desorb or degrade under certain high reservoir temperatures, and usually migrate with the external phase of the OBM and, ultimately, are deposited within the pore-throat regions, with the capability of occluding pore throats.

Therefore, FDM/FDC measures may be found in specially formulated drilling fluids for drilling mixed-layer (illitic + smectitic) and/or kaolinitic sandstone reservoirs. Improvements in the performance of newly formulated drilling fluids in the industry would require detailed analysis and assessment of not only the challenges presented by clay minerals, but also the impact on and interactions of the individual clay mineral species with respect to the drilling fluids' design. Hence, specially designed drilling fluids should be used in the petroleum industry during drilling of kaolinitic sandstone reservoirs or mixed-layer (illite + smectite) and kaolinitic sandstone reservoirs.

\section{Conclusions}

Recently, formation damage mitigation strategies in sandstone reservoirs containing clay minerals have received increasing attention because of their high contribution to the significant reduction in NPT, increased/accelerated production capacity, prevention of well abandonment, prolonged life of fields, cost/rig-time saving, and minimisation of the chances of loss in revenue during drilling programmes. More field activities and the development of FDM/FDC technology have been especially appreciated in both the British and Norwegian sectors of the North Sea.

In this paper, we have summarised numerous contemporary techniques, including the optimisation of the particle size distribution, salinity, $\mathrm{pH}$, and flow rate of RDFs, which play important roles in accelerating the productivity and successful drilling of sandstone reservoirs containing clay minerals. The results of these techniques have improved the principles of FDM/FDC technology for minimising the productivity impairment of sandstone reservoirs with clay minerals. However, existing studies have not given adequate priority to the role of individual species of clay minerals and their varying physicochemical properties in the development of formation damage during the formulation of drilling fluids for sandstone reservoirs with varying clay minerals; rather, clay minerals are most often treated as a whole or single group. Therefore, the impact of drilling fluids of varying formulations on the productivity impairment of reservoir sections containing individual species of varying clay minerals in a microporous or mesoporous structural environment has not been completely understood. This review paper can provide a key reference for current practices on the principles of FDM/FDC methodology used for formulating drilling fluids specifically for kaolinitic sandstone reservoirs, or for formulating drilling fluids specifically for kaolinitic and mixed-layer (illitic + smectitic) sandstone reservoirs.

Author Contributions: Conceptualization, H.H. and M.C.H.; methodology, M.C.H.; investigation, M.C.H.; writing-original draft preparation, M.C.H.; writing-review and editing, A.R.A. and H.H.; supervision, H.H. and A.R.A. All authors have read and agreed to the published version of the manuscript.

Funding: This work was funded by Petroleum Technology Development Fund (PTDF) of Nigeria through the award of a PhD scholarship to Michael Chuks Halim.

Institutional Review Board Statement: Not applicable.

Informed Consent Statement: Not applicable.

Acknowledgments: Michael Chuks Halim gratefully acknowledges the financial support of the Petroleum Technology Development Fund (PTDF) of Nigeria through the award of a PhD scholarship.

Conflicts of Interest: The authors declare that they have no known competing financial interest or personal relationship that could have appeared to influence the work reported in this paper. 


\section{References}

1. Kibria, A.; Akhundjanov, S.B.; Oladi, R. Fossil fuel share in the energy mix and economic growth. Int. Rev. Econ. Financ. 2019, 59, 253-264. [CrossRef]

2. Filimonova, I.; Komarova, A.; Provornaya, I.; Dzyuba, Y.; Link, A. Efficiency of oil companies in Russia in the context of energy and sustainable development. Energy Rep. 2020, 6, 498-504. [CrossRef]

3. International Energy Agency. Energy Database. 2020. Available online: https://www.iea.org/statistics/GoogleScholar (accessed on 11 December 2020).

4. Rui, Z.; Cui, K.; Wang, X.; Chun, J.; Li, Y.; Zhang, Z.; Lu, J.; Chen, G.; Zhou, X.; Patil, S. A comprehensive investigation on performance of oil and gas development in Nigeria: Technical and non-technical analyses. Energy 2018, 158, 666-680. [CrossRef]

5. Epelle, E.; Gerogiorgis, D.I. A review of technological advances and open challenges for oil and gas drilling systems engineering AIChE J. 2020, 66, e16842. [CrossRef]

6. Bennion, D.B. An overview of formation damage mechanisms causing a reduction in the productivity and injectivity of oil and gas producing formations. J. Can. Pet. Technol. 2002, 41, 29-36. [CrossRef]

7. Masikewich, J.; Bennion, D. Fluid design to meet reservoir issues-A process. J. Can. Pet. Technol. 1999, 38, 61-71. [CrossRef]

8. Kang, Y.; Luo, P. Current status and prospect of key techniques for exploration and production of tight sandstone gas reservoirs in China. Pet. Explor. Dev. 2007, 34, 239.

9. Aminian, K.; Bilgesu, H.; Ameri, S. Influence of pore size distribution on damage profile. In Proceedings of the SPE Formation Damage Control Conference, Lafayette, LA, USA, 18-19 February 1998; p. SPE-39587-MS.

10. Caenn, R.; Darley, H.C.; Gray, G.R. Composition and Properties of Drilling and Completion Fluids; Gulf Professional Publishing, Elsevier: Boston, MA, USA, 2011.

11. Zhao, X.; Qiu, Z.; Sun, B.; Liu, S.; Xing, X.; Wang, M. Formation damage mechanisms associated with drilling and completion fluids for deepwater reservoirs. J. Pet. Sci. Eng. 2018, 173, 112-121. [CrossRef]

12. Howard, S.K. Formate brines for drilling and completion: State of the art. In Proceedings of the SPE Annual Technical Conference and Exhibition, Dallas, TX, USA, 22-25 October 1995; p. SPE-30498-MS.

13. Hughes, R.V. The application of modern clay concepts to oilfield development. In Drilling and Production Practice; American Petroleum Institute (API): New York, NY, USA, 1950; pp. 50-151.

14. Todd, A.C.; Tweedie, J.; English, B. Total rock characterisation of north sea sandstones with particular reference to interstitial clays. In Proceedings of the SPE European Petroleum Conference, London, UK, 24-27 October 1978; p. SPE-8118-MS.

15. Yang, Y.; Li, Y.; Yao, J.; Zhang, K.; Iglauer, S.; Luquot, L.; Wang, Z. Formation damage evaluation of a sandstone reservoir via pore-scale X-ray computed tomography analysis. J. Pet. Sci. Eng. 2019, 183, 106356. [CrossRef]

16. Civan, F. Reservoir formation damage; Elsevier: Boston, MA, USA, 2016.

17. Nasr-El-Din, H. New mechanisms of formation damage: Lab studies and case histories. In Proceedings of the SPE European Formation Damage Conference, The Hague, The Netherlands, 13-14 May 2003; p. SPE-82253-MS.

18. Wang, J.Y.; Holditch, S.A.; McVay, D.A. Effect of gel damage on fracture fluid cleanup and long-term recovery in tight gas reservoirs. J. Nat. Gas Sci. Eng. 2012, 9, 108-118. [CrossRef]

19. Krueger, R.F. An overview of formation damage and well productivity in oilfield operations: An update. In Proceedings of the SPE California Regional Meeting, Long Beach, CA, USA, 23-25 March 1988; p. SPE-17459-MS.

20. You, Z.; Bedrikovetsky, P.; Badalyan, A.; Hand, M. Particle mobilization in porous media: Temperature effects on competing electrostatic and drag forces. Geophys. Res. Lett. 2015, 42, 2852-2860. [CrossRef]

21. Chaudhry, A. Gas Well Testing Handbook; Gulf Professional Publishing, Elsevier: Boston, MA, USA, 2003.

22. Sharma, M.M.; Yortsos, Y.C. Fines migration in porous media. AIChE J. 1987, 33, 1654-1662. [CrossRef]

23. Kang, Y.; Yang, B.; You, L.; Chen, Q.; Yu, Y. Damage evaluation of oil-based drill-in fluids to shale reservoirs. Nat. Gas. Ind. 2013, 33, 99-104.

24. Xu, T.; Xiong, Y.; Kang, Y. Technology of Formation Damage Control in Oil and Gas Reservoir; Petroleum Industry Press: Peking, China, 2010.

25. Guedes, R.G.; Al-Abduwani, F.A.; Bedrikovetsky, P.; Currie, P.K. Deep-bed filtration under multiple particle-capture mechanisms. SPE J. 2009, 14, 477-487. [CrossRef]

26. Mungan, N. Permeability reduction through changes in $\mathrm{pH}$ and salinity. J. Pet. Technol. 1965, 17, 1449-1453. [CrossRef]

27. Narayanan, N.; Mohanadhas, B.; Mangottiri, V. Flow and Transport in Subsurface Environment; Springer: Berlin/Heidelberg, Germany, 2018.

28. Kia, S.; Fogler, H.; Reed, M. Effect of pH on colloidally induced fines migration. J. Colloid Interface Sci. 1987, 118, 158-168. [CrossRef]

29. Jensen, J.A.; Radke, C.J. Chromatographic transport of alkaline buffers through reservoir rock. SPE Reserv. Eng. 1988, 3, 849-856. [CrossRef]

30. Jensen, J.A.; Gillis, J.V.; Radke, C.J. Dispersion attendant sodium/hydrogen ion exchange in reservoir sands. SPE Reserv. Eng. 1986, 1, 607-610. [CrossRef]

31. Faergestad, I. The Defining Series: Formation Damage. 2016. Available online: https://www.slb.com/resource-library/oilfieldreview/defining-series/defining-formation-damage (accessed on 6 September 2021).

32. Scott, P.; Davies, M. Souring of new Irian Jaya wells traced to indigeneous bacteria. Oil Gas J. 1993, 91, 47-49. 
33. McGovern-Traa, C.; Leu, J.-Y.; Hamilton, W.A.; Spark, I.S.C.; Patey, I.T.M. The presence of sulphate-reducing bacteria in live drilling muds, core materials and reservoir formation brine from new oilfields. Geol. Soc. London Spéc. Publ. 1997, 124, 229-236. [CrossRef]

34. Kalish, P.J.; Stewart, J.A.; Rogers, W.F.; Bennett, E.O. The Effect of Bacteria on Sandstone Permeability. J. Pet. Technol. 1964, 16, 805-814. [CrossRef]

35. Maudgalya, S.; Knapp, R.M.; McInerney, M. Microbially enhanced oil recovery technologies: A review of the past, present and future. In Proceedings of the SPE Production and Operations Symposium, Oklahoma City, OK, USA, 31 March-3 April 2007; pp. 524-534.

36. Chakraborty, S.; Govindarajan, S.K.; Gummadi, S.N. Numerical modeling on the influence of effective porosity, microbial kinetics, and operational parameters on enhanced oil recovery by microbial flooding within a sandstone formation. SPE J. 2020, 25, 2932-2961. [CrossRef]

37. Wood, J.M.; Spark, I.S. Microbially induced formation damage in oilfield reservoirs. In Proceedings of the SPE International Symposium on Formation Damage Control, Lafayette, LA, USA, 23-24 February 2000; p. SPE-58750-MS.

38. Vaziri, H. Theoretical analysis of stress, pressure, and formation damage during production. J. Can. Pet. Technol. 1988, 27, PETSOC-88-06-13. [CrossRef]

39. Leone, J.A.; Scott, M.E. Characterization and control of formation damage during waterflooding of a high-clay-content reservoir. SPE Reserv. Eng. 1988, 3, 1279-1286. [CrossRef]

40. Hasannejad, R.; Pourafshary, P.; Vatani, A.; Sameni, A. Application of silica nanofluid to control initiation of fines migration. Pet. Explor. Dev. 2017, 44, 850-859. [CrossRef]

41. Reinicke, A.; Rybacki, E.; Stanchits, S.; Huenges, E.; Dresen, G. Hydraulic fracturing stimulation techniques and formation damage mechanisms-Implications from laboratory testing of tight sandstone-proppant systems. Geochemistry 2010, 70, 107-117. [CrossRef]

42. Bedrikovetsky, P.; Vaz, A.; Machado, F.; Zeinijahromi, A.; Borazjani, S. Skin due to fines mobilization, migration, and straining during steady-state oil production. Pet. Sci. Technol. 2012, 30, 1539-1547. [CrossRef]

43. Oliveira, M.A.; Vaz, A.S.; de Siqueira, F.D.; Yang, Y.; You, Z.; Bedrikovetsky, P. Slow migration of mobilised fines during flow in reservoir rocks: Laboratory study. J. Pet. Sci. Eng. 2014, 122, 534-541. [CrossRef]

44. Valdya, R.; Fogler, H. Fines migration and formation damage: Influence of pH and Ion exchange. SPE Prod. Eng. 1992, 7, 325-330. [CrossRef]

45. Jilani, S.; Menouar, H.; Al-Majed, A.; Khan, M. Effect of overbalance pressure on formation damage. J. Pet. Sci. Eng. 2002, 36, 97-109. [CrossRef]

46. Alvarez, A.C.; Hime, G.; Marchesin, D.; Bedrikovetsky, P.G. The inverse problem of determining the filtration function and permeability reduction in flow of water with particles in porous media. Transp. Porous Media 2007, 70, 43-62. [CrossRef]

47. Vaz, A.S.L.; Bedrikovetsky, P.; Furtado, C.J.A.; De Souza, A.L. Well injectivity decline for nonlinear filtration of injected suspension: Semi-analytical model. J. Energy Resour. Technol. 2010, 132, 033301. [CrossRef]

48. You, L.; Kang, Y. Integrated evaluation of water phase trapping damage potential in tight gas reservoirs. In Proceedings of the 8th European Formation Damage Conference, Scheveningen, The Netherlands, 27-29 May 2009; p. SPE-122034-MS.

49. Frequin, D.; Bedrikovetsky, P.; Zitha, P.L. CT scan study of the leak-off of oil-based drilling fluids into saturated media. In Proceedings of the SPE European Formation Damage Conference \& Exhibition, Noordwijk, The Netherlands, 5-7 June 2013; p. SPE-165193-MS.

50. Wuyep, E.; Oluyemi, G.; Yates, K.; Akisanya, A.R. Geomechanical effects of oilfield chemicals on sand failure in reservoir rocks. J. Pet. Sci. Eng. 2018, 165, 347-357. [CrossRef]

51. Reinicke, A.; Blöcher, G.; Zimmermann, G.; Huenges, E.; Dresen, G.; Stanchits, S.; Legarth, B.; Makurat, A. Mechanically induced fracture-face skin-Insights from laboratory testing and modeling approaches. SPE Prod. Oper. 2013, 28, 26-35. [CrossRef]

52. Guo, J.; Liu, Y. Modeling of proppant embedment: Elastic deformation and creep deformation. In Proceedings of the SPE Production and Operations Conference \& Exhibition, Doha, Qatar, 14-16 May 2012; p. SPE-157449-MS.

53. Lin, S.; Lai, B. Experimental investigation of water saturation effects on barnett shale's geomechanical behaviors. In Proceedings of the SPE Annual Technical Conference and Exhibition, New Orleans, LA, USA, 20 September-2 October 2013.

54. Tague, J.R. Overcoming formation damage in heavy oil fields: A comprehensive approach. In Proceedings of the SPE/AAPG Western Regional Meeting, Long Beach, CA, USA, 19-22 June 2000; p. SPE-62546-MS.

55. Mahadevan, J.; Sharma, M.M.; Yortsos, Y.C. Evaporative cleanup of water blocks in gas wells. SPE J. 2007, 12, 209-216. [CrossRef]

56. Kia, S.; Fogler, H.S.; Reed, M.; Vaidya, R.N. Effect of salt composition on clay release in berea sandstones. SPE Prod. Eng. 1987, 2, 277-283. [CrossRef]

57. Khilar, K.C.; Vaidya, R.; Fogler, H. Colloidally-induced fines release in porous media. J. Pet. Sci. Eng. 1990, 4, 213-221. [CrossRef]

58. Veley, C.D. How hydrolyzable metal ions react with clays to control formation water sensitivity. J. Pet. Technol. 1969, 21, 1111-1118. [CrossRef]

59. Leone, J.A.; Scott, E.M. Characterization and control of formation damage during waterflooding of a high-clay-content reservoir. In Proceedings of the SPE Production Operation Symposium, Oklahoma City, OK, USA, 8-10 March 1987; p. SPE-16234-MS.

60. Vaidya, R.; Fogler, H. Formation damage due to colloidally induced fines migration. Colloids Surf. 1990, 50, 215-229. [CrossRef] 
61. Zhang, L.; Zhou, F.; Pournik, M.; Liang, T.; Wang, J.; Wang, Y. An integrated method to evaluate formation damage resulting from water and alkali sensitivity in dongping bedrock reservoir. SPE Reserv. Eval. Eng. 2019, 23, 187-199. [CrossRef]

62. Al-Yami, A.S.; Nasr-El-Din, H.A.; Bataweel, M.A.; Al-Majed, A.A.; Menouar, H. Formation damage induced by various waterbased fluids used to drill HP/HT wells. In Proceedings of the SPE International Symposium and Exhibition on Formation Damage Control, Lafayette, LA, USA, 13-15 February 2008; p. SPE-112421-MS.

63. Alyami, A.S.; Nasr-El-Din, H.A.; Al-Shafei, M.A.; Bataweel, M.A. Impact of water-based drilling-in fluids on solids invasion and damage characteristics. SPE Prod. Oper. 2009, 25, 40-49.

64. Zhang, X.; You, L.; Kang, Y.; Zhang, C.; Zhang, G.; Tan, Q. Formation damage control of saline-lacustrine fractured tight oil reservoir during well drilling. Arab. J. Geosci. 2020, 13, 1087. [CrossRef]

65. Bishop, S.R. The experimental investigation of formation damage due to the induced flocculation of clays within a sandstone pore structure by a high salinity brine. In Proceedings of the SPE European Formation Damage Conference, The Hague, The Netherlands, 2-3 June 1997; p. SPE-38156-MS.

66. Hayatdavoudi, A.; Ghalambor, A. Controlling formation damage caused by kaolinite clay minerals: Part I. In Proceedings of the SPE Formation Damage Control Symposium, Lafayette, LA, USA, 14-15 February 1996; p. SPE-31118-MS.

67. Neasham, J.W. The morphology of dispersed clay in sandstone reservoirs and its effect on sandstone shaliness, pore space and fluid flow properties. In Proceedings of the SPE Annual Fall Technical Conference and Exhibition, Denver, CO, USA, 9-12 October 1977; p. SPE-6858-MS.

68. Xu, Z.; Li, Z.; Wang, C.; Adenutsi, C.D. Experimental study on microscopic formation damage of low permeability reservoir caused by HPG fracturing fluid. J. Nat. Gas Sci. Eng. 2016, 36, 486-495. [CrossRef]

69. Baraka-Lokmane, S.; Main, I.; Ngwenya, B.; Elphick, S. Application of complementary methods for more robust characterization of sandstone cores. Mar. Pet. Geol. 2009, 26, 39-56. [CrossRef]

70. Tang, Y.; Yang, R.; Du, Z.; Zeng, F. Experimental study of formation damage caused by complete water vaporization and salt precipitation in sandstone reservoirs. Transp. Porous Media 2015, 107, 205-218. [CrossRef]

71. Kang, Y.; Xu, C.; You, L.; Yu, H.; Zhang, B. Comprehensive evaluation of formation damage induced by working fluid loss in fractured tight gas reservoir. J. Nat. Gas Sci. Eng. 2014, 18, 353-359. [CrossRef]

72. Jin-Gang, H.; Kang, Y.; You, L. Damage evaluation of fracturing fluids on sandstone reservoir with extra-low permeability. Oilfield Chem. 2013, 30, e178.

73. He, W.; Stephens, M.P. Bridging particle size distribution in drilling fluid and formation damage. In Proceedings of the SPE Formation Damage Conference, Noordwijk, The Netherlands, 7-10 June 2011; p. SPE-143497-MS.

74. Green, J.; Cameron, R.; Patey, I.; Nagassar, V.; Quine, M. Use of micro-CT scanning visualisations to improve interpretation of formation damage laboratory tests including a case study from the south morecambe field. In Proceedings of the SPE European Formation Damage Conference \& Exhibition, Noordwijk, The Netherlands, 5-7 June 2013; p. SPE-165110-MS.

75. Grim, R.E. Modern Concepts of Clay Materials. J. Geol. 1942, 50, 225-275. [CrossRef]

76. Fang, W.; Jiang, H.; Li, J.; Li, W.; Li, J.; Zhao, L.; Feng, X. A new experimental methodology to investigate formation damage in clay-bearing reservoirs. J. Pet. Sci. Eng. 2016, 143, 226-234. [CrossRef]

77. Bin, B.; Rukai, Z.; Songtao, W.; Wenjing, Y.; Gelb, J.; Gu, A.; Zhang, X.; Ling, S. Multi-scale method of Nano (Micro)-CT study on microscopic pore structure of tight sandstone of Yanchang Formation, Ordos Basin. Pet. Explor. Dev. 2013, 40, 354-358.

78. Rezaeizadeh, M.; Hajiabadi, S.H.; Aghaei, H.; Blunt, M.J. Pore-scale analysis of formation damage; A review of existing digital and analytical approaches. Adv. Colloid Interface Sci. 2020, 288, 102345. [CrossRef]

79. Liang, X.; Zhou, F.; Liang, T.; Wang, C.; Li, Y. Experimental quantification of formation damage caused by the cross-linked gel in tight gas reservoirs. J. Nat. Gas Sci. Eng. 2020, 84, 103608. [CrossRef]

80. Wilson, M.; Wilson, L.; Patey, I. The influence of individual clay minerals on formation damage of reservoir sandstones: A critical review with some new insights. Clay Miner. 2014, 49, 147-164. [CrossRef]

81. Zhou, Z.J.; Cameron, S.; Kadatz, B.; Gunter, W.D. Clay swelling diagrams: Their applications in formation damage control. SPE J. 1997, 2, 99-106. [CrossRef]

82. Baker, J.; Uwins, P.; Mackinnon, I. ESEM study of illite/smectite freshwater sensitivity in sandstone reservoirs. J. Pet. Sci. Eng. 1993, 9, 83-94. [CrossRef]

83. Abass, H.; Shebatalhamd, A.; Khan, M.; Al-Shobaili, Y.; Ansari, A.; Ali, S.; Mehta, S. Wellbore instability of shale formation; zuluf field, Saudi Arabia. In Proceedings of the SPE Technical Symposium of Saudi Arabia Section, Dhahran, Saudi Arabia, 6 May 2006; p. SPE-106345-MS.

84. Santarelli, F.; Carminati, S. Do shales swell? A critical review of available evidence. In Proceedings of the SPE/IADC Drilling Conference, Amsterdam, The Netherlands, 28 February-2 March 1995.

85. Méring, J.; Oberlin, A. Smectite. In The Electron Optical Investigation of Clays; Gard, J.A., Ed.; Mineralogical Society: London, UK, 1971; pp. 135-145.

86. Siddig, O.; Mahmoud, A.A.; Elkatatny, S. A review of different approaches for water-based drilling fluid filter cake removal. J. Pet. Sci. Eng. 2020, 192, 107346. [CrossRef]

87. Elkatatny, S.; Ahmed, A.; Abughaban, M.; Patil, S. Deep illustration for loss of circulation while drilling. Arab. J. Sci. Eng. 2020, 45, 483-499. [CrossRef] 
88. Santos, H.; Perez, R. What have we been doing wrong in wellbore stability? In Proceedings of the SPE Latin American and Caribbean Petroleum Engineering Conference, Buenos Aires, Argentina, 25-28 March 2001; p. SPE-69493-MS.

89. Zhang, S.; Jiang, G.; Qing, W.; Wang, L.; Guo, H.; Tang, X.; Bai, D. Low-damaging drilling-in fluid technology used for reservoir protection. Oil Gas Sci. Res. Proj. Inst. State Oil Co. Azerbaijan Repub. (SOCAR) 2014, 1, 24-29. [CrossRef]

90. Vickers, S.; Cowie, M.; Jones, T.; Twynam, A.J. A new methodology that surpasses current bridging theories to efficiently seal a varied pore throat distribution as found in natural reservoir formations. Wiert. Naft. Gaz 2006, 23, 501-515.

91. Wenqiang, F.; Jienian, Y. Designing drill-in fluids by using ideal packing technique. Pet. Sci. 2007, 4, 44-51. [CrossRef]

92. Vickers, S.R.; Cowie, M.S.; Burgess, M.; Anderson, D.A. The application of specifically formulated bridging materials to successfully reduce pore pressure transmission to enable depleted fractured reservoirs to be drilled and produced without incurring formation damage. In Proceedings of the European Formation Damage Conference, Scheveningen, The Netherlands, 30 May-2 June 2007; p. SPE-107753-MS.

93. Abrams, A. Mud design to minimize rock impairment due to particle invasion. J. Pet. Technol. 1977, 29, 586-592. [CrossRef]

94. Smith, P.; Browne, S.; Heinz, T.; Wise, W. Drilling fluid design to prevent formation damage in high permeability quartz arenite sandstones. In Proceedings of the SPE Annual Technical Conference and Exhibition, Denver, CO, USA, 6-9 October 1996; p. SPE-36430-MS.

95. Kaeuffer, M. Determination de l'optimum de remplissage granulometrique et quelques proprietes s'y rattachant. In Proceedings of the Congres De I'AFTPV, Rouen, France, 9-10 October 1973.

96. Dick, M.; Heinz, T.; Svoboda, C.; Aston, M. Optimizing the selection of bridging particles for reservoir drilling fluids. In Proceedings of the SPE International Symposium on Formation Damage Control, Lafayette, LA, USA, 23-24 February 2000; p. SPE-58793-MS.

97. Fleming, N.; Moldrheim, E.; Teigland, E.; Mathisen, A.-M. Systematic approach to well productivity evaluation to determine the significance of formation damage for wells drilled in a depleted reservoir without bridging particles: Oseberg main case history. SPE Prod. Oper. 2020, 35, 681-690. [CrossRef]

98. Downs, J. Formate brines: New solutions to deep slim-hole drilling fluid design problems. In Proceedings of the European Petroleum Conference, Cannes, France, 16-18 November 1992; p. SPE-24973-MS.

99. Gao, C.H. A survey of field experiences with formate drilling fluid. SPE Drill. Complet. 2019, 34, 450-457. [CrossRef]

100. Hossain, M.E.; Al-Majed, A.A. Fundamentals of Sustainable Drilling Engineering; John Wiley \& Sons: Hoboken, NJ, USA, 2015.

101. Bourgoyne, A.T.; Millheim, K.K.; Chenevert, M.E.; Young, F.S. Applied Drilling Engineering; Society of Petroleum Engineers: Richardson, TX, USA, 1986.

102. Karakosta, K.; Mitropoulos, A.C.; Kyzas, G.Z. A review in nanopolymers for drilling fluids applications. J. Mol. Struct. 2020, 1227, 129702. [CrossRef]

103. Bleier, R. Selecting a drilling fluid. J. Pet. Technol. 1990, 42, 832-834. [CrossRef]

104. Abduo, M.; Dahab, A.; Abuseda, H.; AbdulAziz, A.M.; Elhossieny, M. Comparative study of using Water-Based mud containing Multiwall Carbon Nanotubes versus Oil-Based mud in HPHT fields. Egypt. J. Pet. 2016, 25, 459-464. [CrossRef]

105. Collins, N.; Thaemlitz, C. Method for Drilling using a Drilling and Completion Fluid Comprising a Phosphate Based Blend. US8901048B2, 2 December 2014.

106. Alotaibi, M.B.; Nasr-El-Din, H.A.; Hill, A.D. Use of ester as a precursor to clean formate drill-in fluid damage in horizontal wells. SPE Drill. Complet. 2009, 24, 404-412. [CrossRef]

107. Cobianco, S.; Bartosek, M.; Lezzi, A.; Massara, E.P.; Guarneri, A. New solids-free drill-in fluid for low permeability reservoirs. In Proceedings of the SPE International Symposium on Oilfield Chemistry, Houston, TX, USA, 13-16 February 2001; p. SPE-64979-MS.

108. Sangka, N.B.; Budiman, H. New high-density phosphate-based completion fluid: A case history of exploration wells: KRE-1, BOP-1, TBR-1, and KRT-1 in Indonesia. In Proceedings of the SPE Latin American and Caribbean Petroleum Engineering Conference, Lima, Peru, 1-3 December 2010.

109. Svendsen, O.; Toften, J.; Marshall, D.; Hermansson, C. Use of a novel drill-in/completion fluid based on potassium formate brine on the first open hole completion in the gullfaks field. In Proceedings of the SPE/IADC Drilling Conference, Amsterdam, Netherlands, 28 February-2 March 1995; p. SPE-29409-MS. 